\title{
Hereditary Predisposition to Prostate Cancer: From Genetics to Clinical Implications
}

\author{
Andreia Brandão ${ }^{1}$ (D), Paula Paulo ${ }^{1}$ and Manuel R. Teixeira $1,2,3, *$ (D) \\ 1 Cancer Genetics Group, IPO Porto Research Center (CI-IPOP), Portuguese Oncology Institute of \\ Porto (IPO Porto), 4200-072 Porto, Portugal; andreia.aguiar.brandao@ipoporto.min-saude.pt (A.B.); \\ paula.paulo@ipoporto.min-saude.pt (P.P.) \\ 2 Department of Genetics, Portuguese Oncology Institute of Porto (IPO Porto), 4200-072 Porto, Portugal \\ 3 Biomedical Sciences Institute Abel Salazar (ICBAS), University of Porto, 4200-072 Porto, Portugal \\ * Correspondence: manuel.teixeira@ipoporto.min-saude.pt; Tel.: +351-225084000 (ext. 7916)
}

Received: 18 June 2020; Accepted: 13 July 2020; Published: 16 July 2020

\begin{abstract}
Prostate cancer (PrCa) ranks among the top five cancers for both incidence and mortality worldwide. A significant proportion of $\mathrm{PrCa}$ susceptibility has been attributed to inherited predisposition, with $10-20 \%$ of cases expected to occur in a hereditary/familial context. Advances in DNA sequencing technologies have uncovered several moderate- to high-penetrance PrCa susceptibility genes, most of which have previously been related to known hereditary cancer syndromes, namely the hereditary breast and ovarian cancer (BRCA1, BRCA2, ATM, CHEK2, and PALB2) and Lynch syndrome (MLH1, MSH2, MSH6, and PMS2) genes. Additional candidate genes have also been suggested, but further evidence is needed to include them in routine genetic testing. Recommendations based on clinical features, family history, and ethnicity have been established for more cost-efficient genetic testing of patients and families who may be at an increased risk of developing PrCa. The identification of alterations in PrCa predisposing genes may help to inform screening strategies, as well as treatment options, in the metastatic setting. This review provides an overview of the genetic basis underlying hereditary predisposition to $\mathrm{PrCa}$, the current genetic screening recommendations, and the implications for clinical management of the disease.
\end{abstract}

Keywords: prostate cancer; hereditary cancer syndrome; genetic testing; germline variants

\section{Introduction}

Prostate cancer (PrCa) is one of the major causes of morbidity and mortality among men worldwide [1]. According to the American Cancer Society (ACS), PrCa will represent a fifth of all new cancer diagnoses, with an estimated 191,930 new cases and 33,330 deaths, in the United States in 2020 [2].

Despite the substantial burden of $\mathrm{PrCa}$, the established risk factors for this malignancy are limited to age, ethnicity, and a positive family history of the disease [1,3]. In fact, $\mathrm{PrCa}$ incidence and mortality rates are strongly associated with an increasing age, with the average age at diagnosis being 66 years old [4]. They also vary widely across regions and populations, with higher rates among men of African ancestry, and lower rates among those of Asian ancestry [3,5,6]. Epidemiological studies have also revealed that first-degree relatives of a PrCa patient have a two- to three-fold increased risk of developing the disease compared to the general population, and the risk further increases with the number of affected relatives [7]. Similarly, familial aggregation of lethal PrCa has been reported, with first-degree relatives of a patient who died of PrCa having a two-fold increased risk of death from the disease compared with men diagnosed without a family history [8]. To a lesser extent, and not 
consistently, diet and other lifestyle factors, such as smoking and sedentarism, have also been pointed out as contributors to an increased risk of PrCa development [9-12].

It is well-recognized that some of the aforementioned risk factors, such as an early onset of the disease and heavy family history, are strong indicators of genetic susceptibility to PrCa development. This susceptibility has been associated with a complex inheritance of both rare variants in moderate- to high-penetrance genes and common genetic alterations in low-risk genes $[13,14]$. There has been a considerable increasing number of the latter, with approximately 170 common variants identified in large case-control PrCa cohorts [14-19]. However, there is still a lack of solid evidence on their direct association with $\mathrm{PrCa}$ and their clinical utility for screening and management of the disease. Contrarily, germline alterations in high-risk genes, although rare, can have a major influence on treatment decisions [20]. Herein, we examine current knowledge regarding the contribution of germline variation to the inherited predisposition to $\mathrm{PrCa}$, and the clinical impact on the management of the disease and patients' outcome.

\section{Genetic Etiology of Inherited PrCa}

Epidemiological evidence supports a strong genetic contribution to PrCa susceptibility, with $10-20 \%$ of cases expected to occur in a hereditary/familial context [7]. The formal definition of Hereditary $\mathrm{PrCa}(\mathrm{HPC})$ is used to describe families with a strong history of the disease, specifically, families fulfilling the so-called Johns Hopkins criteria, with (1) three or more first-degree relatives diagnosed with $\mathrm{PrCa}$, (2) three successive generations with the disease, or (3) at least two relatives diagnosed with early-onset $\mathrm{PrCa}$ (i.e., before the age of 56 years) [7]. Familial PrCa is a more inclusive concept, used, more commonly, to define familial aggregation of the disease that does not entirely fulfil the HPC criteria (See Chapter 3.1) [21].

Notwithstanding the influence of shared environmental and lifestyle contexts that may account for part of the hereditary/familial manifestation of the disease [22], PrCa exhibits a significant heritable component estimated to have a value of up to 57\% [23]. Interestingly, twin studies have also revealed that unaffected monozygotic twins appear to have a substantially higher risk compared to dizygotic twins when one is diagnosed with $\mathrm{PrCa}$, thus further reinforcing the contribution of genetic factors [23]. This large heritable component has been defined by a complex genetic heterogeneity comprising the inheritance of rare alterations in high-risk/high-penetrance genes, as well as a polygenic inheritance of multiple loci with a cumulative effect in the disease. As a result, and contrarily to other hereditary cancer syndromes, studies have struggled to identify high-penetrance susceptibility genes that explain familial aggregation and/or an early onset of the disease.

\subsection{Rare Variants in Moderate- to High-Penetrance Genes}

Moderate- to high-risk variants are responsible for more than a two-fold increased risk of PrCa in carriers compared to the general population [24]. Though usually rare in most populations $(<1 \%$ of the population), these variants may present a higher prevalence in isolated or more consanguineous populations, due to founder effects [25]. To date, a considerable number of studies have examined the genetic landscape of inherited PrCa. The genes more consistently recognized to affect PrCa susceptibility, thus recommended for genetic testing by the National Comprehensive Cancer Network (NCCN) guidelines for $\mathrm{PrCa}$, are summarized in Table 1, with the distribution of reported pathogenic/likely pathogenic variants illustrated in Figure 1. In addition, a few candidate genes that have also been proposed, though with less consistent findings, are also described.

With the continuous advancement of next-generation sequencing (NGS) technologies, a new era of molecular diagnosis, characterized by the simultaneous analysis of multiple susceptibility genes, has led to the identification of rare variants in several genes of moderate- to high-penetrance in hereditary cancer syndromes [26,27]. In fact, most of the genes contributing to an inherited predisposition to $\mathrm{PrCa}$ were identified by the observed occurrence of PrCa cases in families with known hereditary cancer syndromes, namely hereditary breast and ovarian cancer (HBOC) and Lynch syndrome (LS) [28-30], 
with only the HOXB13 gene being specifically associated with an increased risk of HPC [31]. The use of multigene panel testing has highlighted the possible pan-cancer involvement of key signaling pathways in hereditary cancer predisposition, rather than cancer-specific drivers. This observation could leverage the identification of novel targetable pathways/genes transversal to hereditary syndromes, decreasing inter-patient heterogeneity and improving clinical management.

\subsubsection{The HOXB13 Homeobox B13 (HOXB13) Gene}

In 2012, a recurrent variant (G84E) was identified in the homeobox transcription factor HOXB13 gene, localized on chromosome 17, through linkage analysis of a subset of familial/hereditary and early-onset PrCa patients of European ancestry [31]. The HOXB13 gene interacts with the androgen receptor (AR), playing a critical role in the regulation of cellular growth and differentiation during normal development of the prostate gland [32]. In this initial report, the HOXB13 G84E variant was twenty times more frequent in PrCa patients compared with healthy controls, and significantly more common in patients with a positive family history and early-onset $\operatorname{PrCa}$ than in those with non-familial late-onset $\mathrm{PrCa}$ [31]. Subsequent studies have confirmed a more modest association with an increased risk of PrCa, particularly in the familial/hereditary setting [33-39]. Interestingly, the G84E variant has been observed almost exclusively in men of European ancestry, suggesting a possible founder effect [40]. Additional HOXB13 alterations have been reported in specific populations that do not present the G84E variant, such as the G135E variant in the Chinese population [41], or the A128D and F240L variants in the Portuguese population [42]. To date, HOXB13 remains the most widely replicated and specific PrCa susceptibility gene.

\subsubsection{The HBOC Genes}

HBOC, an inherited disorder that predisposes to a substantial lifetime risk of breast and ovarian cancers [43-47], is mostly attributed to pathogenic variants in either breast cancer gene 1 or breast cancer gene 2 (BRCA1 and $B R C A 2$, respectively) [48]. BRCA1 and BRCA2 are tumor suppressor genes localized on chromosomes 17 and 13, respectively. The proteins encoded by BRCA1 and BRCA2 are known to function in homologous recombination (HR), a vital DNA repair pathway for ensuring genome integrity [49]. Germline alterations in these genes have been associated with an increased risk of other malignancies, including $\mathrm{PrCa}$, pancreatic cancer, and melanoma [50-52]. Specifically in PrCa, studies have reported that BRCA1 pathogenic variants confer a 1.8-fold to 3.8-fold increased relative risk (RR) of diagnosis by the age of $\leq 65$ years old $[53,54]$. Although variants in both of these genes have been associated with a more aggressive disease and poor clinical outcome, alterations in the $B R C A 2$ gene are more established in PrCa predisposition. Reports have shown that pathogenic variants in BRCA2 may account for about $5 \%$ of the familial clustering of $\mathrm{PrCa}$, and confer an increased $\mathrm{RR}$ of 2.5 -fold to 8.6 -fold by the age of 65 years old [55-58]. Carrier men $\leq 55$ years old seem to be considerably more susceptible to PrCa development, with an RR ranging from 7.8 to 23 [55,58]. Moreover, germline alterations in the BRCA2 gene have been appointed as independent predictors of a younger age of diagnosis, more aggressive phenotype, and higher mortality rate compared with non-carriers [55,59-62]. The study of germline alterations in the BRCA1/2 genes is particularly important in the identification of population-specific founder variants, e.g., in the Ashkenazim Jewish population, it is estimated that approximately $2 \%$ of the population carries at least one of three founder mutations in BRCA1 (185delA or 5382insC) and BRCA2 (6174delT) [63].

\subsubsection{The LS Genes}

LS, previously known as hereditary nonpolyposis colorectal cancer (HNPCC), is one of the major causes of an inherited susceptibility to colorectal cancer, often associated with other cancers $[64,65]$. LS is an inherited autosomal dominant cancer-susceptibility disorder derived from germline pathogenic variants in four DNA mismatch repair (MMR) genes: mutL homologue 1 (MLH1), mutS homologue 2 and 6 (MSH2 and MSH6, respectively), and postmeiotic segregation increased 2 (PMS2) [66-68]. 
Additionally, promoter hypermethylation leading to a loss of $M S H 2$ expression, due to the deletion of the epithelial cell adhesion molecule (EPCAM) gene, is described as a cause of LS in $1-3 \%$ of the families [69,70].

LS primarily predisposes to colorectal and endometrial cancer [66], although several other extracolonic cancers have been reported within the Lynch tumor spectrum, including gastric, small bowel, pancreatic, brain, and urothelial neoplasms [64,71]. A higher incidence of PrCa among families with Lynch syndrome, or in men harboring pathogenic variants in the MMR genes, has also been consistently described $[28,29,72]$. Nevertheless, previous studies assessing the PrCa risk in families with LS have yielded conflicting results, with some studies reporting a high incidence of PrCa among male carriers of defective MMR genes [73], and others not finding a significant PrCa risk association [74,75]. Haraldsdotti et al. [29] reinforced PrCa as a possible component of LS, reporting a nearly five-fold increased risk of developing the disease in men with LS; however, no association with age at diagnosis and aggressiveness was found. Additionally, studies have also highlighted a considerably higher PrCa risk for carriers of germline alterations in the MSH2 gene compared to MLH1 and MSH6 carriers $[73,76,77]$.

\subsubsection{The Ataxia Telangiectasia Mutated (ATM) and Checkpoint Kinase 2 (CHEK2) Genes}

The ATM and CHEK2 genes, located on chromosome 11 and 22, respectively, encode tumor suppressor genes that participate in the DNA-damage signaling pathway. The ATM serine threonine kinase responds to DNA-damage by phosphorylating downstream proteins involved in DNA repair and/or cell-cycle control [78]. One of those proteins is CHEK2, a cell-cycle checkpoint protein kinase that, upon ATM-mediated activation, will trigger DNA repair or cell cycle arrest/apoptosis through p53 activation, among other effectors [79]. Homozygous germline alterations in the ATM gene result in ataxia telangiectasia syndrome, which is characterized by a variety of pathological manifestations, including an increased predisposition for several cancer forms, such as breast, colorectal, gastric, and pancreatic cancers [80]. Alterations in the CHEK2 gene have been consistently associated with an increased risk for breast cancer development $[81,82]$ and, more recently, with other types of cancer, such as colorectal and kidney cancers [82-84].

ATM and CHEK2 are among the first DNA repair genes for which recurrent germline loss-of-function variants were found in families with an aggregation of PrCa [85-88]. Recently, using targeted sequencing to screen 94 genes associated with inherited cancer predisposition in a series of 121 early-onset/familial PrCa patients, Paulo et al. [89] identified potentially pathogenic $\operatorname{PrCa}$ predisposing germline variants in $14.9 \%$ of the cases, with the most commonly mutated genes being ATM (5.8\%) and CHEK2 (3.3\%), altogether representing $61.1 \%$ of the identified carriers. Pritchard and collaborators [90] reported the germline mutational profile of 20 DNA repair genes in a multicenter cohort of 692 patients with metastatic PrCa, unselected for a family history of cancer or age at diagnosis. The study revealed that $11.8 \%$ of the PrCa patients harbored germline alterations in 16 genes, with ATM and CHEK2 representing the second (1.6\%) and third (1.9\%) most frequently affected genes, after BRCA2 (5.3\%). Moreover, these authors also observed a significantly higher prevalence of germline alterations in the CHEK2 gene in the metastatic compared to localized form of PrCa; however no association with age at diagnosis or family history of the disease was reported. A similar prevalence of germline variants in DNA repair genes was also reported in patients with lethal PrCa in Finnish and Swedish populations unselected for family history [91]. A total of $12.3 \%$ of the lethal PrCa cases presented potentially damaging protein-truncating variants in DNA repair genes, with ATM (3.3\%) and CHEK2 $(4.1 \%)$ being the genes most frequently altered. This accumulating evidence supports a strong association of germline alterations in the ATM and CHEK2 genes with an increased risk of developing PrCa, especially the more aggressive and lethal form of the disease. 


\subsubsection{The Partner and Localizer of BRCA2 (PALB2) Gene}

PALB2 is localized on chromosome 16 and encodes a BRCA2 binding protein that acts a physical linker between $B R C A 1$ and $B R C A 2$ to form a "BRCA complex" essential in the HR repair mechanism [92]. While biallelic loss-of-function alterations in this gene lead to Fanconi anemia [93], heterozygous germline alterations have been primarily associated with an increased risk of breast and pancreatic cancers $[82,94,95]$. Although rare, deleterious germline variants in PALB2 have also been observed in PrCa patients [82,90,96-98]. Nicolosi and colleagues reported pathogenic PALB2 germline variants in $17(0.56 \%)$ unselected PrCa patients [98]. Likewise, a trend towards aggressive disease has also been suggested, with Pritchard et al. [90] reporting defective PALB2 in $0.4 \%$ of men with metastatic PrCa. Notwithstanding the rarity of PALB2 aberrations reported in those studies, recent findings have supported an increasing role of PALB2 in the disease, particularly in the clinical management of metastatic PrCa $[99,100]$.

\subsubsection{Other Candidate DNA Repair Genes}

A few less-studied candidate genes have been proposed to be associated with inherited cancer predisposition, including PrCa predisposition. One of the proposed candidate genes is the BRCA1-interacting protein C-terminal helicase 1 (BRIP1) gene located on chromosome 17. BRIP1 is a helicase that binds directly to the $B R C A 1$ gene in the HR process, playing a role in the double-strand DNA break repair mechanism [101]. Initial studies have identified germline BRIP1 variants in BRCA1/2 mutation-negative breast and ovarian cancer patients $[102,103]$. Similarly, a few studies have reported potentially deleterious variants in BRIP1 in PrCa patients [89,96,98,104]. Kote-Jarai and colleagues [104] found a moderate risk of PrCa (OR: 2.4, 95\% CI: 0.25-23.4) in a set of familial and young-onset PrCa patients carrying a recurrent $B R I P 1$ truncating variant. Interestingly, a subsequent study observed the same recurrent variant (c.2392C $>$ T) in two PrCa families, further suggesting the involvement of the BRIP1 gene in familial PrCa predisposition [87].

Another gene of interest is the Nijmegen Breakage Syndrome 1 (NBS1) gene, also known as Nibrin $(N B N)$. This gene, located on chromosome 8, is also involved in the double-strand DNA break repair complex [105]. The NBS1 gene has been proposed as a candidate PrCa susceptibility gene, particularly for the familial/hereditary form [106]. A specific founder variant in this gene (c.657del5) has been associated with a three-fold increased risk of PrCa below the age of 60 years, and a four-fold increased risk for male carriers with a positive family history [88]. Interestingly, carriers of this variant also experience more aggressive disease and mortality. Recent PrCa studies have reported additional pathogenic variants in this gene $[90,107]$.

Several other inherited alterations in DNA repair genes associated with different hereditary cancers have been identified in PrCa studies, such as in the RAD51C, RAD51D, and TP53 genes [87,89,90,98]. However, there is still very little data available to support or refute the existence of such associations, so further studies with an expanded set of genes within these pathways are needed to validate these and other proposed candidates as PrCa susceptibility genes. 
Table 1. Genes associated with an elevated risk of prostate cancer (PrCa).

\begin{tabular}{|c|c|c|c|c|}
\hline Gene & OMIM & PrCa Risk * & Frequency $(\%)$ & Reference \\
\hline \multicolumn{5}{|c|}{ PrCa Predisposing Genes Recommended for Genetic Testing } \\
\hline ATM & 607585 & $\begin{array}{c}\text { Unselected OR: } 2.1 \\
\text { Metastatic RR: } 6.3-7.4\end{array}$ & $\begin{array}{c}7.4 \% \\
1.6-1.9 \%\end{array}$ & {$[90,108,109]$} \\
\hline$B R C A 1$ & 113705 & $\begin{array}{c}\text { Unselected RR: } 1.8-3.8 \\
\text { Early-onset, OR: } 1.9 \ddagger(95 \% \mathrm{CI} \text { : } \\
0.7-5.1) \\
\text { Metastatic RR, 3.9-5.3 }\end{array}$ & $\begin{array}{c}0.5 \% \\
0.8 \% \\
0.9-1 \%\end{array}$ & {$[53,54,88,90,109]$} \\
\hline$B R C A 2$ & 600185 & $\begin{array}{c}\text { Unselected RR: } 2.9-4.7 \\
\text { Early-onset RR: 7.8-23 } \\
\text { Metastatic, RR: } 11.5-18.6\end{array}$ & $\begin{array}{c}1.2 \% \\
0.8-2.3 \% \\
3.3-5.4 \%\end{array}$ & $\begin{array}{c}{[55,57,58,90,109} \\
110]\end{array}$ \\
\hline CHEK2 & 604373 & $\begin{array}{c}\text { Unselected OR: } 1.8-3.3 \\
\text { Familial/HPC, OR: } 2.7-8.2 \\
\text { Early-onset, OR } 2.4 \\
\text { Metastatic, RR: } 3.1\end{array}$ & $\begin{array}{c}0.05-3.8 \% \\
1.2-10.2 \% \\
2.6 \% \\
0.5-1.9 \%\end{array}$ & $\begin{array}{c}{[82,85,86,88,90,109} \\
111,112]\end{array}$ \\
\hline HOXB13 (G84E) & 604607 & $\begin{array}{l}\text { Unselected OR: 2-8.7 } \\
\text { Familial, OR: } 6.6-20.1 \\
\text { Early-onset, OR, } 8.6\end{array}$ & $\begin{array}{c}0.5-4.6 \% \\
3.1-8.2 \% \\
0.5-10.3 \%\end{array}$ & {$[31,38,39,113]$} \\
\hline $\begin{array}{l}\text { MMR genes } \\
(M L H 1, M S H 2, \\
\text { MSH6, PMS2) }\end{array}$ & 120436 & $\begin{array}{c}\text { Unselected RR: 1.9-3.7 } \\
\text { Familial/Early-onset } \\
\text { Metastatic, RR: } 1.9-6.0 \ddagger(95 \% \mathrm{CI} \text { : } \\
0.05-45)\end{array}$ & $\begin{array}{c}0.4 \% \\
0.2-0.6 \%\end{array}$ & {$[28,30,90,109,114]$} \\
\hline PALB2 & 610355 & $\begin{array}{c}\text { Unselected OR: } 0.5-2.1 \ddagger(95 \% \text { CI: } \\
\text { 0.2-7.1) } \\
\text { Metastatic, RR: } 3.5 \ddagger(95 \% \text { CI: } \\
0.7-10.3)\end{array}$ & $\begin{array}{l}0.1 \% \\
0.4 \%\end{array}$ & {$[82,90]$} \\
\hline
\end{tabular}

\begin{tabular}{|c|c|c|c|c|}
\hline \multicolumn{5}{|c|}{ Novel Candidate PrCa Predisposing Genes } \\
\hline \multirow{2}{*}{ BRIP1 } & \multirow{2}{*}{605882} & $\begin{array}{c}\text { Familial/Early-onset, OR, } 2.4 \ddagger \\
\text { (95\% CI: } 0.25-23.4)\end{array}$ & $0.1 \%$ & \multirow[t]{2}{*}{90,104} \\
\hline & & $\begin{array}{c}\text { Metastatic, RR: } 0.9 \ddagger(95 \% \text { CI: } \\
0.02-5.3)\end{array}$ & $0.2 \%$ & \\
\hline \multirow{4}{*}{$\begin{array}{l}\text { NBS1 } \\
\text { (c.657del5) }\end{array}$} & \multirow{4}{*}{251260} & Unselected OR: 2.5-3.9 & $1.4-2.2 \%$ & \multirow{4}{*}{88,106} \\
\hline & & Familial, OR: 4.3-16 & $2.4-9.0 \%$ & \\
\hline & & Early-onset, OR: 3.1 & $1.8 \%$ & \\
\hline & & $\begin{array}{c}\text { Metastatic, RR: } 2.5 \ddagger(95 \% \text { CI: } \\
0.3-9.1)\end{array}$ & $0.3 \%$ & \\
\hline RAD51D & 602954 & Metastatic, RR: 5.7 & $0.4 \%$ & [90] \\
\hline
\end{tabular}

* PrCa risk estimates combine odds ratios and relative risks, depending on the study. Early-onset was considered for diagnosis under the age of 56 years old, with the exception of the study from Cybulski et al. [88] ( $\leq 60$ years old).

$\ddagger$ Statistically non-significant PrCa risk association. 


\section{HR genes}

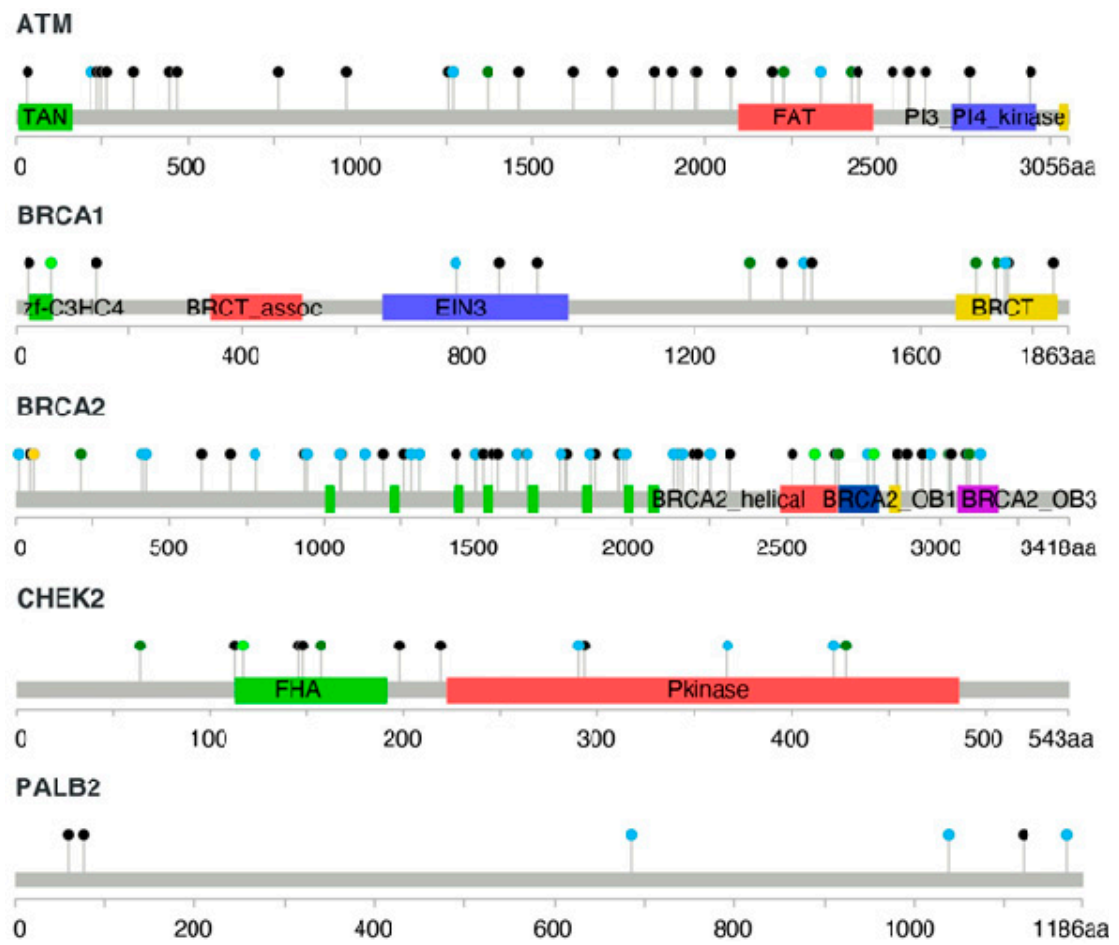

\section{MMR genes}

MLH1

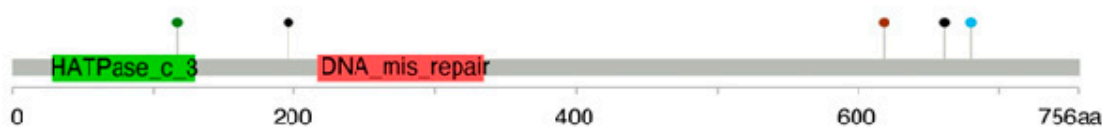

MSH2

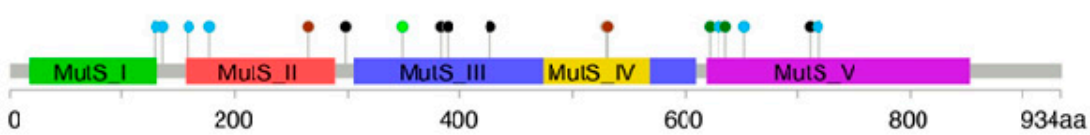

MSH6

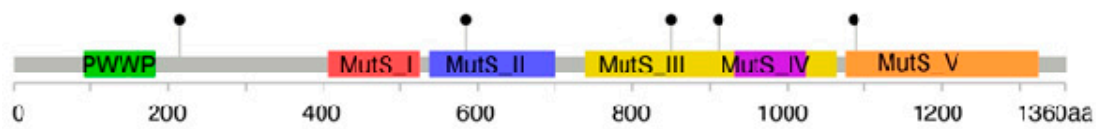

\section{PMS2}

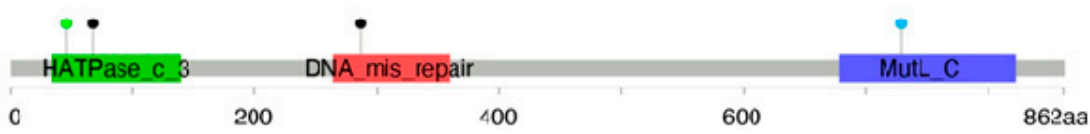

0

$200-400$

- Missense - Missense (early-onset / familial PrCa)

- Inframe Inframe (early-onset / familial PrCa)

- Truncating Truncating (early-onset / familial PrCa)

Figure 1. Pathogenic germline variants reported in the established, and potentially clinically actionable, PrCa predisposing genes recommended for genetic testing for PrCa [30,53,55,58,82,87-90,96,115-120] (Table S1). Missense variants classified as "pathogenic/likely pathogenic" by ClinVar (https://www.ncbi. nlm.nih.gov/clinvar/, accessed in 20 May 2020) are also represented on each gene. The location of the variants is shown by lollipop structures. The x-axis represents the number of amino acid residues and displays the protein domains encoded by each gene. 


\subsection{Common Low-Penetrance Loci Identified by GWAS}

Over the years, extensive linkage and candidate gene analyses have been undertaken to unravel the hereditary basis of PrCa; however, the number of high-risk genes identified remains relatively scarce. Recently, agnostic approaches, such as genome-wide association studies (GWAS), have become the gold standard to query numerous loci without having to specify particular candidate genes [121,122]. This approach has led to the discovery of common risk loci (i.e., frequency of $5 \%$ or higher in the general population) in a vast number of complex diseases and traits, including several types of cancer $[123,124]$. Figure 2 illustrates the distribution of loci significantly associated with $\operatorname{PrCa}\left(p\right.$-value $\left.\leq 5.0 \times 10^{-8}\right)$, listed in the NHGRI-EBI Catalogue of published GWASs: http://www.ebi.ac.uk/gwas (for more details, see Table S2).

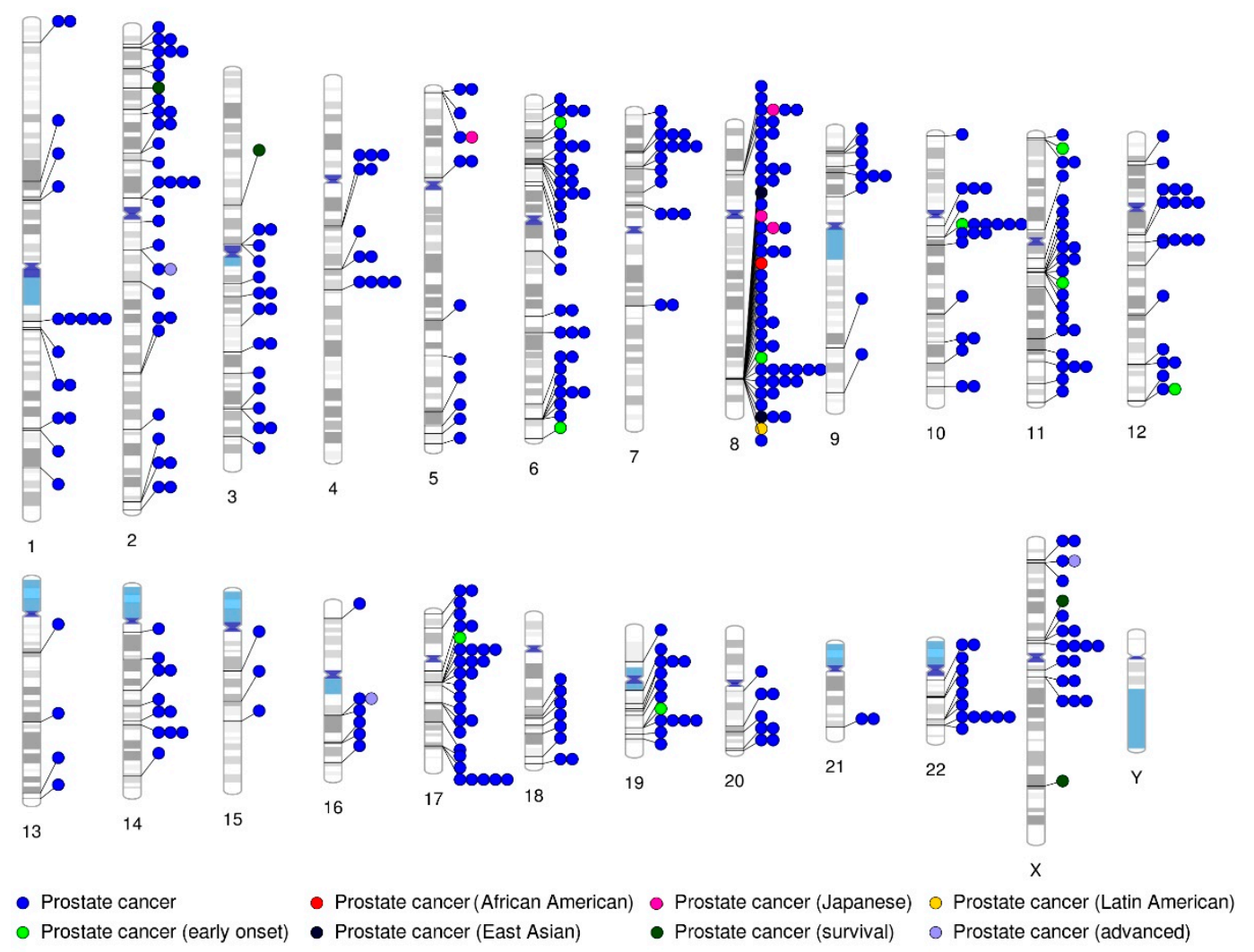

Figure 2. PrCa risk loci identified by genome-wide association studies (GWAS). The circles represent the location of loci significantly associated with PrCa risk ( $p$-value $\leq 5.0 \times 10^{-8}$ ) along the genome, divided into separate chromosomes. Data retrieved from the NHGRI-EBI Catalogue of published GWAS (http://www.ebi.ac.uk/gwas) and plotted using the PhenoGram software.

Overall, large case-control GWAS have uncovered approximately 170 common low-penetrance susceptibility loci (typically, individually ORs $<2$ ) that, in combination, may explain over $30 \%$ of the familial relative risk (FRR) of PrCa in European ancestry populations [14,15,125]. Likewise, a few additional loci have also been significantly associated with an increased risk for PrCa in non-European populations, suggesting population-specific differences in the frequency of certain risk loci [126-128]. Importantly, a particular susceptibility region on chromosome $8 \mathrm{q} 24$ has been vastly replicated across racial/ethnic populations as a major contributor to PrCa risk [129-131]. The overall contribution of the germline variation at $8 \mathrm{q} 24$ has been estimated to account for $25 \%$ of the total FRR explained by known genetic risk factors for PrCa, which is greater than any other known GWAS locus [130].

Most of the GWAS-identified PrCa risk loci are located on non-coding regions of the genome, for which biological interpretation is considerably challenging [132]. Nevertheless, strong efforts have been made to develop novel analytical methods to explore the biological mechanisms underlying these 
susceptibility loci and to identify new gene networks and signaling pathways in PrCa $[133,134]$. As a result, several common susceptibility loci have been reported to have effects on prostate tumorigenesis, by affecting the expression of multiple genes $[135,136]$ and influencing several important cell signaling pathways (extensively reviewed elsewhere $[125,134,137])$. For example, some risk loci have been reported to alter the binding of important PrCa-associated transcription factors, such as the AR and HOXB13 $[138,139]$. Despite these promising results, the clinical utility of GWAS findings remains uncertain, as more studies are still needed to assess and validate whether, when combined, these common risk variants (e.g., through polygenic risk scores) may have clinical relevance for identifying and/or stratifying men at risk of PrCa $[125,134,140]$. Moreover, to date, the majority of GWAS findings have performed poorly in terms of discriminating between indolent and aggressive/lethal forms of $\mathrm{PrCa}$, which is instrumental for clinical management of the disease [15,141]. Therefore, although increasing efforts from large multi-ethnic consortiums continue to unravel new risk loci for PrCa [14], GWAS findings are still not recommended in the NCCN guidelines for clinical use at the time of writing [142].

\section{Genetic Testing}

\subsection{Criteria for Genetic Counseling and Genetic Testing}

As in other inherited cancer predisposing syndromes, genetic testing for PrCa risk assessment has major implications at both an individual and familial level, namely psychological and social, but also raises ethical, legal, and financial questions [143-145]. It is therefore essential to evaluate, based on family history or specific clinical criteria, the cost-effectiveness and actionability of the genetic screening and to identify individuals/families at a high risk of PrCa development or disease progression, who would benefit the most. In fact, with emerging evidence sustaining the importance of the genetic landscape in clinical management of the disease, there has been an effort, in the last years, to establish guidelines for the genetic risk assessment of patients with PrCa. According to the updated version of the NCCN guidelines for PrCa (version 2.2020) [142], referral for genetic counseling and genetic testing should be considered for all PrCa patients with a family history of high-risk germline variants (particularly in genes associated with HR or MMR pathways-Figure 1), or with an Ashkenazi Jewish heritage, because of the high prevalence of founder BRCA1/2 alterations. In addition, patients with a suspicious family history, defined by the NCCN guidelines as having a heavy family history of $\mathrm{PrCa}$ (with direct relative or multiple family members diagnosed with PrCa before the age of 60 years old), or with three or more cancers (breast, colorectal, endometrial, gastric, ovarian, pancreatic, prostate, melanoma, kidney, bile duct, small bowel, or urothelial cancer) on the same side of the family before the age of 50 years old, also meet the criteria for genetic counseling and genetic testing [142].

In the absence of the aforementioned criteria, the histopathological features of the disease can also be important for referring patients for genetic testing. The presence of intraductal carcinoma is considered a criterion for genetic counseling and genetic testing, as this is a well-known adverse prognostic factor that has been associated with pathogenic germline DNA repair gene alterations in men with PrCa [146-148]. Furthermore, the NCCN guidelines also suggest genetic testing for patients with localized high-risk and very-high-risk regional or metastatic PrCa [142].

Although a young age at diagnosis is not included in the NCCN recommendations for genetic testing, it has been argued that men with an early onset of the disease could benefit from genetic risk evaluation [149]. Furthermore, as early-onset PrCa cases are likely to be enriched for genetic susceptibility to $\mathrm{PrCa}[30,89,150]$, first-degree relatives of the affected individuals may have an increased hereditary predisposition, so referral for genetic counseling and testing might be beneficial.

These criteria highlight the importance of pre-test genetic counseling visits for obtaining a thorough personal and family cancer history of the patient presenting for PrCa risk evaluation. Furthermore, genetic counseling has an essential role, not only in providing patients with clinical information regarding the potential cancer risk for the proband and their first-degree relatives, the risk of recurrence, 
available testing procedures and limitations, and possible follow-up procedures, but also, ultimately, in helping the patient to make informed decisions [151,152].

In the absence of a known pathogenic germline alteration, the recommendations for PrCa risk assessment and screening are usually based on the personal and/or family cancer history. Therefore, in the case of a heavy family history, genetic counseling may be considered to discuss possible participation in family or variant reclassification studies [142].

\subsection{Genes Recommended for Genetic Testing}

The advances in NGS technologies have greatly facilitated the use of multigene panel testing for hereditary cancer risk evaluation and management in clinical practice. For PrCa, multigene panel testing has driven the identification of several alterations in genes of moderate-penetrance (usually with an RR of 2- to 5-fold) contributing to the complex and heterogeneous genetic architecture of $\operatorname{PrCa}[87,89,90,96,118]$. As previously described, inherited alterations in DNA-damage repair genes have been consistently implicated in $\mathrm{PrCa}$, being described in a range of $5 \%$ to $12 \%$ of the localized and metastatic stages of the disease, respectively [90].

Given the association between certain germline variants and an increased PrCa risk, the NCCN has established a list of recommended genes for genetic testing [142]. Therefore, according to the updated NCCN guidelines, PrCa patients fulfilling the criteria for genetic risk evaluation described in the previous section should be considered for germline testing by NGS multigene panels containing, at least, the HR genes BRCA1, BRCA2, ATM, CHEK2, and PALB2 and the MMR genes MLH1, MSH2, $M S H 6$, and PMS2. Additional genes are also recommended to be included in specific research or clinical contexts. For instance, HOXB13 does not have a clear therapeutic implication, but it is important for hereditary family risk assessment $[31,36,42]$. As the use of multigene panel testing tackling the PrCa genomic heterogeneity continues to increase, it is expected that this list of genes will continue to be updated.

Upon the identification of a pathogenic germline alteration in a moderate- to high-risk gene, referral for genetic counseling is recommended to evaluate the risk of second primary tumors, as well as possible therapeutic implications (described in the next section) [153]. Additionally, the confirmation of hereditary cancer predisposition can prompt cascade counseling and the testing of additional at-risk family members and help implement carrier screening and/or prophylaxis of PrCa $[153,154]$. In fact, both the NCCN and the European Association of Urology (EAU) guidelines for the early detection of PrCa recommend the surveillance of prostate-specific antigen (PSA) levels from the age of 40 years old for men carrying BRCA1/2 deleterious variants [154,155]. The ACS also recommends beginning PrCa screening at the age of 40 years old for men with a heavy family history of PrCa (i.e., with more than one first-degree relative affected by $\mathrm{PrCa}<65$ years old) and, slightly later, at the age of 45 years old, for men with only one first-degree relative diagnosed with $\mathrm{PrCa}$ under 65 years old [156]. Screening/prophylaxis for other cancers may be recommended, depending on the risks associated with the specific gene mutated in the family.

Although beyond the scope of this review, it is worth mentioning that the spectrum of somatic genetic alterations in PrCa tumors is also important in clinical management of the disease. Therefore, NCCN guidelines also recommend multigene panel testing of somatic alterations in the HR and MMR genes for patients with regional or metastatic PrCa. Furthermore, numerous studies have reported that somatic tumor sequencing can lead to the identification of germline defects. Robinson and colleagues reported that $8 \%$ of the alterations found in tumors of metastatic castration-resistant prostate cancer (mCRPC) patients occurred in the germline [157]. Therefore, it is recommended that, if somatic alterations are found in HR or MMR genes, the PrCa patients should be referred for genetic counseling to assess the possibility of the cancer having arisen in the context of HBOC or LS syndromes [142]. 


\subsection{Therapeutic Impact of Genetic Testing}

As previously stated, the identification of pathogenic variants in genes mediating DNA-damage repair mechanisms in men with $\mathrm{PrCa}$ can have several therapeutic implications. The determination of defective DNA repair genes is important for providing information on disease prognosis and severity, as they have been consistently associated with a higher incidence of early-onset, more aggressive clinical behavior and cancer-specific mortality $[13,90,91,158]$. Moreover, the incidence of DNA repair alterations is significantly higher in advanced metastatic PrCa [90]. Among the genes recommended for the genetic testing of $\operatorname{PrCa}$, the BRCA2 gene, responsible for the highest risk of PrCa known to date, has the most well-established prognostic value [61,159]. Carriers of a defective BRCA2 gene have been reported to have higher rates of metastatic relapse and PrCa-specific mortality, even after treatment for local/locally advanced disease [61,160]. Indeed, a multicenter study has recommended systematic PSA screening for men carrying $B R C A 2$ alterations for the early detection of clinically intermediate/high-risk PrCa [60].

The identification of deleterious alleles, inherited and/or acquired, in the BRCA2 and other DNA repair genes can also be clinically useful in terms of providing predictive biomarkers for individualized treatment options. In disseminated disease, mCRPC patients with deleterious germline variants in the BRCA1/2 and ATM genes have shown improved responses to second-generation androgen deprivation therapy (ADT) and abiraterone or enzalutamide therapy [117]. Furthermore, this particular group of PrCa patients has also been reported to have sustained responses to innovative targeted therapies, such as poly-ADP ribose polymerase (PARP) inhibitors $[20,99,100,161,162]$. PARPs play an important role in DNA-damage repair pathways, being responsible for the repair of single-strand DNA breaks by base excision repair (BER). If not repaired prior to the DNA replication process, these single-stranded breaks may result in double-stranded breaks, thus compromising the cell genomic integrity [163]. Furthermore, recently, it has also been shown that PARP inhibition accelerates replication fork elongation, leading to increased DNA replication stress and genomic instability [164]. Interestingly, this contrasts with the accepted model, in which inhibitors of PARPs block cellular replication by inducing stalling or collapsing of the replication fork [165]. In the event of PARP inactivation, proteins involved in the HR pathway, including $B R C A 1, B R C A 2$, and PALB2, compensate for the PARP blockade by repairing the double-stranded breaks. However, in the case of defective DNA-damage repair genes, these cells are not able to address the accumulating double-stranded breaks, ultimately leading to the loss of cell viability $[163,166]$. Taking this premise into consideration, several basket trials have been established to evaluate tumor responses in patients with similar defective DNA repair genetic profiles, regardless of the tumor histology [167-169]. For PrCa, a phase II clinical trial documented that $88 \%$ of heavily pretreated mCRPC patients that responded to a PARP inhibitor (olaparib), many for more than 12 months, carried defects in DNA repair genes (mainly, BRCA2 and $A T M$ ) [20]. In a subsequent phase III study comparing the efficacy of olaparib with a second line of ADT in MCRPC patients with at least one deleterious variant in one of several HR repair genes, a significant benefit with olaparib was observed for imaging-based progression-free survival, the objective response rate, and the median time to pain progression [100]. As a result, the use of olaparib (LYNPARZA, AstraZeneca Pharmaceuticals, LP), previously approved by the Food and Drug Administration (FDA) for treating breast, ovarian, and pancreatic cancers harboring BRCA1 or BRCA2 variants, was, very recently, extended to treat $\mathrm{mCRPC}$ patients with deleterious or suspected deleterious germline/somatic alterations in any of 14 HR genes (ATM, BRCA1, BRCA2, BARD1, BRIP1, CDK12, CHEK1, CHEK2, FANCL, PALB2, RAD51B, RAD51C, RAD51D, and RAD54L), who have progressed following prior treatment with second-generation ADT therapy. Additionally, a phase II study with the PARP inhibitor rucaparib reported PSA and objective response rates in $54 \%$ and $48 \%$, respectively, of the mCRPC patients with a deleterious BRCA1/2 alteration [170]. Interestingly, no objective responses were observed in patients with $A T M$ alterations. These results also rendered the FDA's approval of rucaparib (Rubraca ${ }^{\circledR}$, Clovis Oncology Inc.) for mCRPC patients with deleterious BRCA alterations (germline and/or somatic) previously treated with ADT and a taxane-based chemotherapy. In addition 
to PARP inhibition therapy, emerging evidence has suggested that DNA repair defects may also be predictive for a higher likelihood of a response to carboplatin-based chemotherapy in MCRPC. Pomerantz and colleagues reported that $75 \%$ of the mCRPC carriers of the defective BRCA2 gene, treated with carboplatin and docetaxel, experienced a PSA decline $>50 \%$ within 12 weeks, compared to $17 \%$ of non-carriers [171]. Additionally, a recent study also reported exceptional and durable responses to carboplatin-based treatment in three mCRPC patients with strong family histories and different DNA repair defect profiles [172].

The detection of germline and/or somatic alterations in MMR genes also has therapeutic implications, as it may help to predict immunotherapy benefits among a specific subset of $\operatorname{PrCa}$ patients. Recently, Antonarakis and colleagues [173] reported that men with advanced PrCa harboring MMR deficiency appear to have a particular sensitivity to hormonal therapies (ADT, abiraterone/enzalutamide), as well as anecdotal responses to programmed cell death protein-1 ligand (PD-1) inhibitors. Other clinical studies have reported mCRPC patients with complete, or partial, responses to PD-1 inhibitors $[174,175]$. Based on the available data, the FDA has recently approved the PD-1 inhibitor pembrolizumab (KEYTRUDA) for the treatment of unresectable or metastatic microsatellite instability-high (MSI-H)/MMR-deficient solid tumors which have progressed since prior treatment and have no alternative treatment options, including PrCa [176]. Concordantly, current NCCN guidelines support the use of pembrolizumab in patients with MSI-H or MMR-deficient mCRPC, whose disease has progressed through at least one line of systemic therapy [177]. These novel genetically-targeted therapeutic modalities support the relevance of genetic testing in the clinical management of the disease, particularly for metastatic PrCa patients that are no longer responding to classic therapies.

Additionally, based on the described frequency of primary prostate carcinomas (The Cancer Genome Atlas) with actionable alterations in other targetable oncogenic pathways, such as PI3K or MAPK [119], enlarged somatic multigene testing of PrCa tumors could unveil other subsets of patients that could benefit from targeted treatment.

\subsection{Limitations of Genetic Testing}

One of the most significant challenges inherent to genetic testing is the assessment of the pathogenicity of variants of an uncertain significance (VUS). The classification of VUS relies on the fact that the available data is insufficient to interpret the finding as either benign or pathogenic, making it difficult to infer the clinical implications for the patients carrying them. Therefore, contrary to pathogenic variants, it is recommended that VUS are handled as a non-actionable finding, as they do not assist with clinical diagnosis or management $[178,179]$. As the use of multigene panels rapidly expands in hereditary cancer predisposition testing, the percentage of VUS classification is expected to increase. Nevertheless, advances in computational resources have enabled the integration of massive amounts of data from genomics, proteomics, and other omics, with clinical information, aiding in the definition of the clinical significance of VUS. For instance, a large retrospective study comprising 1.45 million individuals and 1.67 million initial tests reported that $7.7 \%$ of the variants, initially classified as VUS, were reclassified [178]. The vast majority of the variant reclassifications were downgraded to benign/likely benign ( $91 \%)$, with only a small fraction being upgraded to pathogenic/likely pathogenic $(\sim 9 \%)$. Importantly, the authors also attested that the reclassification of variants initially defined as benign or pathogenic was rare.

Another potential challenge in genetic screening is the identification of unexpected incidental or secondary findings resulting from the large amount of genomic data generated. By definition, incidental findings refer to findings that are clearly, or expected to be, of clinical relevance, but unrelated to the original indication for testing [180]. These additional findings raise difficulties for the laboratory and clinicians, in terms of deciding which findings should be conveyed to patients. Although guidelines for managing and reporting incidental findings are still limited, and somewhat inconsistent, the American College of Medical Genetics and Genomics (ACMG) has released a set of recommendations 
for reporting incidental findings in 59 clinically actionable genes associated with several pathologies, including inherited cancer syndromes [181].

Lastly, it is worth mentioning that, although genetic testing should ideally provide the information required to facilitate cancer risk assessment for the proband and potential at-risk family members, the fact still remains that a large proportion of high-risk PrCa families are negative for all known cancer predisposing genes [89], and must continue to be clinically guided solely based on their personal and/or family history [89].

\section{Conclusions}

Hereditary susceptibility is one of the most important risk factors for PrCa development and has profound clinical importance. Despite extensive research, the genetic mechanism behind such susceptibility is still largely elusive. So far, an increased risk for PrCa has mainly been associated with only a handful of rare pathogenic germline variants in moderately to highly-penetrant DNA-damage repair and LS-associated genes. Contrarily, GWAS have reported numerous common loci of modest effects that, combined, may explain a large portion of the excess FRR of PrCa. However, the clinical utility of these risk loci remains uncertain. The identification of both high- and low-penetrance alterations can have a major clinical impact on the management of $\mathrm{PrCa}$, from pre-test genetic counseling to tailored screening and risk assessment. Genetic testing also has a key role on treatment decisions in metastatic disease. mCRPC patients with alterations in HR genes (e.g., BRCA1, BRCA2, $A T M, C H E K 2$, and PALB2) may benefit from carboplatin-based chemotherapy and PARP inhibitors, whereas MCRPC patients presenting microsatellite instability and MMR-deficient genes (e.g., MLH1, MSH2, MSH6, and PMS2) appear to have sensibility to PD-1 inhibitors. The increasing use of multigene panel testing in the clinical setting is expected to further help in characterization of the genomic profile underlying the inherited predisposition to $\mathrm{PrCa}$. This may contribute to an improved risk assessment, informed therapeutic decisions, and, ultimately, better long-term outcomes for PrCa patients and carrier relatives.

Supplementary Materials: Supplementary materials can be found at http://www.mdpi.com/1422-0067/21/14/ 5036/s1.

Author Contributions: A.B. wrote the original paper draft. P.P. and M.R.T. were involved in the review and editing of the manuscript. All authors have read and agree to the published version of the manuscript.

Funding: We would like to thank the funding support from IPO-Porto Research Center (CI-IPOP-16-2012) and Fundação para a Ciência e a Tecnologia (FCT; PEst-OE/SAU/UI0776/2014; PTDC/DTP-PIC/1308/2014 and PTDC/MED-GEN/28245/2017). The following authors were awarded grants from FCT: A.B. (UID/DTP/00776/2013/POCI-01-0145-FEDER-006868) and P.P. (CEECINST/00091/2018). The funders had no role in the preparation of the manuscript.

Conflicts of Interest: The authors declare no conflicts of interest. The founding sponsors had no role in the design of the study; in the collection, analyses, or interpretation of data; in the writing of the manuscript; and in the decision to publish the results.

$\begin{array}{ll}\text { Abbreviations } \\ \text { ACS } & \text { American Cancer Society } \\ \text { ADT } & \text { Androgen deprivation therapy } \\ \text { ATM } & \text { Ataxia telangiectasia mutated } \\ \text { BRCA1 } & \text { Breast cancer gene 1 } \\ \text { BRCA2 } & \text { Breast cancer gene 2 } \\ \text { BRIP1 } & \text { BRCA-interacting protein C-terminal helicase 1 } \\ \text { CHEK2 } & \text { Checkpoint kinase 2 } \\ \text { EAU } & \text { European Association of Urology } \\ \text { EPCAM } & \text { Epithelial cell adhesion molecule } \\ \text { FDA } & \text { Food and Drug Administration } \\ \text { FRR } & \text { Familial relative risk }\end{array}$




$\begin{array}{ll}\text { GWAS } & \text { Genome-wide association studies } \\ \text { HBOC } & \text { Hereditary breast and ovarian cancer } \\ \text { HNPCC } & \text { Hereditary nonpolyposis colorectal cancer } \\ \text { HOXB13 } & \text { Homeobox B13 } \\ \text { HPC } & \text { Hereditary prostate cancer } \\ \text { HR } & \text { Homologous recombination } \\ \text { LS } & \text { Lynch Syndrome } \\ \text { mCRPC } & \text { Metastatic castration-resistant PrCa } \\ \text { MLH1 } & \text { MutL homologue 1 } \\ \text { MMR } & \text { Mismatch repair } \\ \text { MSH2 } & \text { MutS homologue 2 } \\ \text { MSH6 } & \text { MutS homologue 6 } \\ \text { MSI-H } & \text { Microsatellite instability-high } \\ \text { NBN } & \text { Nibrin } \\ \text { NBS1 } & \text { Nijmegen Breakage Syndrome 1 } \\ \text { NCCN } & \text { National Comprehensive Cancer Network } \\ \text { PALB2 } & \text { Partner and localizer of BRCA2 } \\ \text { PARP } & \text { Poly(adenosine diphosphate-ribose) polymerase } \\ \text { PD-1 } & \text { Programmed cell death protein-1 ligand } \\ \text { PMS2 } & \text { Postmeiotic segregation increased } \\ \text { PrCa } & \text { Prostate cancer } \\ \text { PSA } & \text { Prostate-specific antigen } \\ \text { RR } & \text { Relative risk } \\ & \end{array}$

\section{References}

1. Pernar, C.H.; Ebot, E.M.; Wilson, K.M.; Mucci, L.A. The epidemiology of prostate cancer. Cold Spring Harb. Perspect. Med. 2018, 8, a030361. [CrossRef]

2. Siegel, R.L.; Miller, K.D.; Jemal, A. Cancer statistics, 2020. CA: A Cancer J. Clin. 2020, 70, 7-30. [CrossRef] [PubMed]

3. Taitt, H.E. Global Trends and Prostate Cancer: A Review of Incidence, Detection, and Mortality as Influenced by Race, Ethnicity, and Geographic Location. Am. J. Men's Heal. 2018, 12, 1807-1823. [CrossRef]

4. Brandt, A.; Bermejo, J.L.; Sundquist, J.; Hemminki, K. Age at Diagnosis and Age at Death in Familial Prostate Cancer. Oncologist 2009, 14, 1209-1217. [CrossRef] [PubMed]

5. Rebbeck, T.R.; Devesa, S.S.; Chang, B.-L.; Bunker, C.H.; Cheng, I.; Cooney, K.; Eeles, R.; Fernandez, P.; Giri, V.N.; Gueye, S.M.; et al. Global Patterns of Prostate Cancer Incidence, Aggressiveness, and Mortality in Men of African Descent. Prostate Cancer 2013, 2013, 1-12. [CrossRef] [PubMed]

6. Odedina, F.T.; Akinremi, T.O.; Chinegwundoh, F.; Roberts, R.; Yu, D.; Reams, R.R.; Freedman, M.L.; Rivers, B.M.; Green, B.L.; Kumar, N.B. Prostate cancer disparities in Black men of African descent: A comparative literature review of prostate cancer burden among Black men in the United States, Caribbean, United Kingdom, and West Africa. Infectious Agents Cancer 2009, 4, S2. [CrossRef] [PubMed]

7. Carter, B.S.; Bova, G.S.; Beaty, T.H.; Steinberg, G.D.; Childs, B.; Isaacs, W.B.; Walsh, P.C. Hereditary Prostate Cancer: Epidemiologic and Clinical Features. J. Urol. 1993, 150, 797-802. [CrossRef]

8. Brandt, A.; Sundquist, J.; Hemminki, K. Risk for incident and fatal prostate cancer in men with a family history of any incident and fatal cancer. Ann. Oncol. 2012, 23, 251-256. [CrossRef]

9. Rogers, L.Q.; Courneya, K.S.; Paragi-Gururaja, R.; Markwell, S.J.; Imeokparia, R. Lifestyle behaviors, obesity, and perceived health among men with and without a diagnosis of prostate cancer: A population-based, cross-sectional study. BMC Public Health 2008, 8, 23. [CrossRef]

10. John, E.M.; Stern, M.C.; Sinha, R.; Koo, J. Meat consumption, cooking practices, meat mutagens, and risk of prostate cancer. Nutr. Cancer 2011, 63, 525-537. [CrossRef]

11. Mandair, D.; Rossi, R.E.; Pericleous, M.; Whyand, T.; Caplin, M.E. Prostate cancer and the influence of dietary factors and supplements: A systematic review. Nutr. Metab. 2014, 11, 30. [CrossRef] [PubMed]

12. Benke, I.; Leitzmann, M.; Behrens, G.; Schmid, D. Physical activity in relation to risk of prostate cancer: A systematic review and meta-analysis. Ann. Oncol. 2018, 29, 1154-1179. [CrossRef] [PubMed] 
13. Castro, E.; Eeles, R. The role of BRCA1 and BRCA2 in prostate cancer. Asian J. Androl. 2012, 14, 409-414. [CrossRef] [PubMed]

14. Schumacher, F.R.; Al Olama, A.A.; Berndt, S.I.; Benlloch, S.; Ahmed, M.; Saunders, E.J.; Dadaev, T.; Leongamornlert, D.; Anokian, E.; Cieza-Borrella, C.; et al. Association analyses of more than 140,000 men identify 63 new prostate cancer susceptibility loci. Nat. Genet. 2018, 50, 928-936. [CrossRef] [PubMed]

15. Al Olama, A.A.; Kote-Jarai, Z.; Berndt, S.I.; Conti, D.V.; Schumacher, F.; Han, Y.; Benlloch, S.; Hazelett, D.J.; Wang, Z.; Saunders, E.; et al. A meta-analysis of 87,040 individuals identifies 23 new susceptibility loci for prostate cancer. Nat. Genet. 2014, 46, 1103-1109. [CrossRef] [PubMed]

16. Du, Z.; Hopp, H.; Ingles, S.A.; Huff, C.; Sheng, X.; Weaver, B.; Stern, M.; Hoffmann, T.J.; John, E.M.; Van Den Eeden, S.K.; et al. A genome-wide association study of prostate cancer in Latinos. Int. J. Cancer 2019, 146, 1819-1826. [CrossRef]

17. Wang, M.; Takahashi, A.; Liu, F.; Ye, D.; Ding, Q.; Qin, C.; Yin, C.; Zhang, Z.; Matsuda, K.; Kubo, M.; et al. Large-scale association analysis in Asians identifies new susceptibility loci for prostate cancer. Nat. Commun. 2015, 6, 8469. [CrossRef]

18. Marzec, J.; Mao, X.; Li, M.; Wang, M.; Feng, N.; Gou, X.; Wang, G.; Sun, Z.; Xu, J.; Xu, H.; et al. A genetic study and meta-analysis of the genetic predisposition of prostate cancer in a Chinese population. Oncotarget 2016, 7, 21393-21403. [CrossRef]

19. Takata, R.; Takahashi, A.; Fujita, M.; Momozawa, Y.; Saunders, E.J.; Yamada, H.; Maejima, K.; Nakano, K.; Nishida, Y.; Hishida, A.; et al. 12 new susceptibility loci for prostate cancer identified by genome-wide association study in Japanese population. Nat. Commun. 2019, 10, 4422-4510. [CrossRef]

20. Mateo, J.; Carreira, S.; Sandhu, S.K.; Miranda, S.; Mossop, H.; Perez-Lopez, R.; Rodrigues, D.N.; Robinson, D.; Omlin, A.; Tunariu, N.; et al. DNA-Repair Defects and Olaparib in Metastatic Prostate Cancer. N. Engl. J. Med. 2015, 373, 1697-1708. [CrossRef]

21. Stanford, J.L.; Ostrander, E.A. Familial Prostate Cancer. Epidemiol. Rev. 2001, 23, 19-23. [CrossRef] [PubMed]

22. Sundquist, K.; Sundquist, J.; Ji, J. Contribution of shared environmental factors to familial aggregation of common cancers. Eur. J. Cancer Prev. 2015, 24, 162-164. [CrossRef] [PubMed]

23. Mucci, L.; Hjelmborg, J.; Harris, J.R.; Czene, K.; Havelick, D.J.; Hviid, T.V.F.; Graff, R.E.; Holst, K.; Möller, S.; Unger, R.; et al. Familial Risk and Heritability of Cancer among Twins in Nordic Countries. JAMA 2016, 315, 68-76. [CrossRef] [PubMed]

24. Tung, N.; Domchek, S.M.; Stadler, Z.; Nathanson, K.L.; Couch, F.; Garber, J.E.; Offit, K.; Robson, M. Counselling framework for moderate-penetrance cancer-susceptibility mutations. Nat. Rev. Clin. Oncol. 2016, 13, 581-588. [CrossRef]

25. Stanislaw, C.; Xue, Y.; Wilcox, W.R. Genetic evaluation and testing for hereditary forms of cancer in the era of next-generation sequencing. Cancer Boil. Med. 2016, 13, 55-67. [CrossRef]

26. Domchek, S.M.; Bradbury, A.R.; Garber, J.E.; Offit, K.; Robson, M. Multiplex Genetic Testing for Cancer Susceptibility: Out on the High Wire Without a Net? J. Clin. Oncol. 2013, 31, 1267-1270. [CrossRef]

27. Paulo, P.; Pinto, P.; Peixoto, A.; Santos, C.; Pinto, C.; Rocha, P.; Veiga, I.; Soares, G.; Machado, C.; Ramos, F.; et al. Validation of a Next-Generation Sequencing Pipeline for the Molecular Diagnosis of Multiple Inherited Cancer Predisposing Syndromes. J. Mol. Diagn. 2017, 19, 502-513. [CrossRef]

28. Raymond, V.M.; Mukherjee, B.; Wang, F.; Huang, S.-C.; Stoffel, E.M.; Kastrinos, F.; Syngal, S.; Cooney, K.; Gruber, S.B. Elevated Risk of Prostate Cancer among Men With Lynch Syndrome. J. Clin. Oncol. 2013, 31, 1713-1718. [CrossRef]

29. Haraldsdottir, S.; Hampel, H.; Wei, L.; Wu, C.; Frankel, W.; Bekaii-Saab, T.; De La Chapelle, A.; Goldberg, R.M. Prostate cancer incidence in males with Lynch syndrome. Genet. Med. 2014, 16, 553-557. [CrossRef]

30. Maia, S.; Cardoso, M.; Paulo, P.; Pinheiro, M.; Pinto, P.; Santos, C.; Pinto, C.; Peixoto, A.; Henrique, R.; Teixeira, M.R. The role of germline mutations in the BRCA1/2 and mismatch repair genes in men ascertained for early-onset and/or familial prostate cancer. Fam. Cancer 2015, 15, 111-121. [CrossRef]

31. Ewing, C.M.; Ray, A.M.; Lange, E.M.; Zuhlke, K.A.; Robbins, C.M.; Tembe, W.D.; Wiley, K.E.; Isaacs, S.D.; Johng, D.; Wang, Y.; et al. Germline Mutations inHOXB13and Prostate-Cancer Risk. N. Engl. J. Med. 2012, 366, 141-149. [CrossRef] [PubMed]

32. Norris, J.D.; Chang, C.Y.; Wittmann, B.M.; Kunder, R.S.; Cui, H.; Fan, D.; Joseph, J.D.; McDonnell, D.P.; Stein, R. The Homeodomain Protein HOXB13 Regulates the Cellular Response to Androgens. Mol. Cell 2009, 36, 405-416. [CrossRef] [PubMed] 
33. Breyer, J.P.; Avritt, T.G.; McReynolds, K.M.; Dupont, W.D.; Smith, J.R. Confirmation of the HOXB13 G84E germline mutation in familial prostate cancer. Cancer Epidemiol. Biomarkers Prev. 2012, 21, 1348-1353. [CrossRef] [PubMed]

34. Laitinen, V.H.; Wahlfors, T.; Saaristo, L.; Rantapero, T.; Pelttari, L.; Kilpivaara, O.; Laasanen, S.-L.; Kallioniemi, A.; Nevanlinna, H.; Aaltonen, L.; et al. HOXB13 G84E Mutation in Finland: Population-Based Analysis of Prostate, Breast, and Colorectal Cancer Risk. Cancer Epidemiol. Biomarkers Prev. 2013, 22, 452-460. [CrossRef]

35. Shang, Z.; Zhu, S.; Zhang, H.; Li, L.; Niu, Y. Germline Homeobox B13 (HOXB13) G84E Mutation and Prostate Cancer Risk in European Descendants: A Meta-analysis of 24213 Cases and 73631 Controls. Eur. Urol. 2013, 64, 173-176. [CrossRef] [PubMed]

36. Handorf, E.; Crumpler, N.; Gross, L.; Giri, V.N. Prevalence of the HOXB13 G84E mutation among unaffected men with a family history of prostate cancer. J. Genet. Couns. 2013, 23, 371-376. [CrossRef]

37. Kote-Jarai, Z.; Mikropoulos, C.; Leongamornlert, D.A.; Dadaev, T.; Tymrakiewicz, M.; Saunders, E.; Jones, M.; Jugurnauth-Little, S.; Govindasami, K.; Guy, M.; et al. Prevalence of theHOXB13 G84E germline mutation in British men and correlation with prostate cancer risk, tumour characteristics and clinical outcomes. Ann. Oncol. 2015, 26, 756-761. [CrossRef]

38. Xu, J.; Lange, E.M.; Lu, L.; Zheng, S.L.; Wang, Z.; Thibodeau, S.N.; Cannon-Albright, L.A.; Teerlink, C.C.; Camp, N.J.; Johnson, A.M.; et al. HOXB13 is a susceptibility gene for prostate cancer: Results from the International Consortium for Prostate Cancer Genetics (ICPCG). Qual. Life Res. 2012, 132, 5-14. [CrossRef]

39. Beebe-Dimmer, J.L.; Hathcock, M.; Yee, C.; Okoth, L.A.; Ewing, C.M.; Isaacs, W.B.; Cooney, K.; Thibodeau, S.N. The HOXB13 G84E Mutation Is Associated with an Increased Risk for Prostate Cancer and Other Malignancies. Cancer Epidemiol. Biomarkers Prev. 2015, 24, 1366-1372. [CrossRef]

40. Chen, Z.; Greenwood, C.M.; Isaacs, W.B.; Foulkes, W.D.; Sun, J.; Zheng, S.L.; Condreay, L.D.; Xu, J. The G84E mutation of HOXB13 is associated with increased risk for prostate cancer: Results from the REDUCE trial. Carcinogenesis 2013, 34, 1260-1264. [CrossRef]

41. Lin, X.; Qu, L.; Chen, Z.; Xu, C.; Ye, D.; Shao, Q.; Wang, X.; Qi, J.; Chen, Z.; Zhou, F.; et al. A novel Germline mutation inHOXB13is associated with prostate cancer risk in Chinese men. Prostate 2012, 73, 169-175. [CrossRef] [PubMed]

42. Maia, S.; Cardoso, M.; Pinto, P.; Pinheiro, M.; Santos, C.; Peixoto, A.; Bento, M.J.; Oliveira, J.; Henrique, R.; Jerónimo, C.; et al. Identification of Two Novel HOXB13 Germline Mutations in Portuguese Prostate Cancer Patients. PLoS ONE 2015, 10, e0132728. [CrossRef] [PubMed]

43. Chen, S.; Parmigiani, G. Meta-Analysis of BRCA1 and BRCA2 Penetrance. J. Clin. Oncol. 2007, 25, 1329-1333. [CrossRef] [PubMed]

44. Risch, H.A.; McLaughlin, J.R.; Cole, D.E.C.; Rosen, B.; Bradley, L.; Kwan, E.; Jack, E.; Vesprini, D.J.; Kuperstein, G.; Abrahamson, J.L.A.; et al. Prevalence and Penetrance of Germline BRCA1 and BRCA2 Mutations in a Population Series of 649 Women with Ovarian Cancer. Am. J. Hum. Genet. 2001, 68, 700-710. [CrossRef] [PubMed]

45. Mavaddat, N.; Peock, S.; Frost, D.; Ellis, S.; Platte, R.; Fineberg, E.; Evans, D.G.; Izatt, L.; Eeles, R.; Adlard, J.; et al. Cancer Risks for BRCA1 and BRCA2 Mutation Carriers: Results From Prospective Analysis of EMBRACE. J. Natl. Cancer Inst. 2013, 105, 812-822. [CrossRef]

46. King, M.C.; Marks, J.H.; Mandell, J.B. Breast and Ovarian Cancer Risks Due to Inherited Mutations in BRCA1 and BRCA2. Science 2003, 302, 643-646. [CrossRef]

47. Lee, Y.C.; Milne, R.; Lheureux, S.; Friedlander, M.; McLachlan, S.; Martin, K.; Bernardini, M.; Smith, C.; Picken, S.; Nesci, S.; et al. Risk of uterine cancer for BRCA1 and BRCA2 mutation carriers. Eur. J. Cancer 2017, 84, 114-120. [CrossRef]

48. Kobayashi, H.; Ohno, S.; Sasaki, Y.; Matsuura, M. Hereditary breast and ovarian cancer susceptibility genes. Oncol. Rep. 2013, 30, 1019-1029. [CrossRef]

49. Roy, R.; Chun, J.; Powell, S.N. BRCA1 and BRCA2: Different roles in a common pathway of genome protection. Nat. Rev. Cancer 2011, 12, 68-78. [CrossRef]

50. Mersch, J.; Jackson, M.A.; Park, M.; Nebgen, D.R.; Peterson, S.K.; Singletary, C.N.; Arun, B.K.; Litton, J.K. Cancers associated with BRCA1 and BRCA2 mutations other than breast and ovarian. Cancer 2014, 121, 269-275. [CrossRef] 
51. Mano, R.; Tamir, S.; Kedar, I.; Benjaminov, O.; Baniel, J.; Tabachnik, T.; Margel, D. Malignant Abnormalities in Male BRCA Mutation Carriers. JAMA Oncol. 2018, 4, 872. [CrossRef] [PubMed]

52. Moran, A.; O’Hara, C.; Khan, S.; Shack, L.; Woodward, E.; Maher, E.R.; Lalloo, F.; Evans, D.G. Risk of cancer other than breast or ovarian in individuals with BRCA1 and BRCA2 mutations. Fam. Cancer 2011, 11, $235-242$. [CrossRef]

53. Leongamornlert, D.; Collaborators, T.U.; Mahmud, N.; Tymrakiewicz, M.; Saunders, E.; Dadaev, T.; Castro, E.; Goh, C.; Govindasami, K.; Guy, M.; et al. Germline BRCA1 mutations increase prostate cancer risk. Br. J. Cancer 2012, 106, 1697-1701. [CrossRef]

54. Thompson, D.; Easton, D.F. Cancer Incidence in BRCA1 Mutation Carriers. Obstet. Gynecol. Surv. 2003, 58, 27-28. [CrossRef]

55. Kote-Jarai, Z.; Collaborators, T.U.; Leongamornlert, D.; Saunders, E.; Tymrakiewicz, M.; Castro, E.; Mahmud, N.; Guy, M.; Edwards, S.; O’Brien, L.; et al. BRCA2 is a moderate penetrance gene contributing to young-onset prostate cancer: Implications for genetic testing in prostate cancer patients. Br. J. Cancer 2011, 105, 1230-1234. [CrossRef]

56. Easton, D.F. Breast Cancer Linkage Consortium Cancer Risks in BRCA2 Mutation Carriers. J. Natl. Cancer Inst. 1999, 91, 1310-1316. [CrossRef] [PubMed]

57. Agalliu, I.; Karlins, E.; Kwon, E.M.; Iwasaki, L.M.; Diamond, A.; Ostrander, E.A.; Stanford, J.L. Rare germline mutations in the BRCA2 gene are associated with early-onset prostate cancer. Br. J. Cancer 2007, 97, 826-831. [CrossRef] [PubMed]

58. Edwards, S.M.; Kote-Jarai, Z.; Meitz-Hopkins, J.; Hamoudi, R.; Hope, Q.; Osin, P.; Jackson, R.; Southgate, C.; Singh, R.; Falconer, A.; et al. Two Percent of Men with Early-Onset Prostate Cancer Harbor Germline Mutations in the BRCA2 Gene. Am. J. Hum. Genet. 2003, 72, 1-12. [CrossRef]

59. Gallagher, D.; Gaudet, M.M.; Pal, P.; Kirchhoff, T.; Balistreri, L.; Vora, K.; Bhatia, J.; Stadler, Z.; Fine, S.W.; Reuter, V.; et al. Germline BRCA mutations denote a clinicopathologic subset of prostate cancer. Clin. Cancer Res. 2010, 16, 2115-2121. [CrossRef]

60. Page, E.C.; Bancroft, E.K.; Brook, M.N.; Assel, M.; Al Battat, M.H.; Thomas, S.; Taylor, N.; Chamberlain, A.; Pope, J.; Ni Raghallaigh, H.; et al. Interim Results from the IMPACT Study: Evidence for Prostate-specific Antigen Screening in BRCA2 Mutation Carriers. Eur. Urol. 2019, 76, 831-842. [CrossRef]

61. Castro, E.; Goh, C.; Leongamornlert, D.A.; Saunders, E.; Tymrakiewicz, M.; Dadaev, T.; Govindasami, K.; Guy, M.; Ellis, S.; Frost, D.; et al. Effect of BRCA Mutations on Metastatic Relapse and Cause-specific Survival After Radical Treatment for Localised Prostate Cancer. Eur. Urol. 2015, 68, 186-193. [CrossRef] [PubMed]

62. Thorne, H.; Willems, A.J.; Niedermayr, E.; Hoh, I.M.; Li, J.; Clouston, D.; Mitchell, G.; Fox, S.B.; Hopper, J.L.; Bolton, D.; et al. Decreased Prostate Cancer-Specific Survival of Men with BRCA2 Mutations from Multiple Breast Cancer Families. Cancer Prev. Res. 2011, 4, 1002-1010. [CrossRef] [PubMed]

63. Roa, B.B.; Boyd, A.A.; Volcik, K.; Richards, C.S. Ashkenazi Jewish population frequencies for common mutations in BRCA1 and BRCA2. Nat. Genet. 1996, 14, 185-187. [CrossRef] [PubMed]

64. Lynch, H.T.; Snyder, C.L.; Shaw, T.G.; Heinen, C.D.; Hitchins, M.P. Milestones of Lynch syndrome: 1895-2015. Nat. Rev. Cancer 2015, 15, 181-194. [CrossRef]

65. Haraldsdottir, S.; Rafnar, T.; Frankel, W.L.; Einarsdottir, S.; Sigurdsson, A.; Hampel, H.; Snaebjornsson, P.; Masson, G.; Weng, D.; Arngrimsson, R.; et al. Comprehensive population-wide analysis of Lynch syndrome in Iceland reveals founder mutations in MSH6 and PMS2. Nat. Commun. 2017, 8, 14755. [CrossRef]

66. Bonadona, V.; Bonaiti, B.; Olschwang, S.; Grandjouan, S.; Huiart, L.; Longy, M.; Guimbaud, R.; Buecher, B.; Bignon, Y.-J.; Caron, O.; et al. Cancer Risks Associated With Germline Mutations in MLH1, MSH2, and MSH6 Genes in Lynch Syndrome. JAMA 2011, 305, 2304-2310. [CrossRef]

67. Balmaña, J.; Stockwell, D.H.; Steyerberg, E.W.; Stoffel, E.M.; Deffenbaugh, A.M.; Reid, J.E.; Ward, B.; Scholl, T.; Hendrickson, B.; Tazelaar, J.; et al. Prediction of MLH1 and MSH2 Mutations in Lynch Syndrome. JAMA 2006, 296, 1469. [CrossRef]

68. Broeke, S.T.; Van Der Klift, H.M.; Tops, C.M.; Aretz, S.; Bernstein, I.T.; Buchanan, D.D.; De La Chapelle, A.; Capellà, G.; Clendenning, M.; Engel, C.; et al. Cancer Risks for PMS2-Associated Lynch Syndrome. J. Clin. Oncol. 2018, 36, 2961-2968. [CrossRef]

69. Tutlewska, K.; Lubiński, J.; Kurzawski, G. Germline deletions in the EPCAM gene as a cause of Lynch syndrome - literature review. Hered. Cancer Clin. Pr. 2013, 11, 9. [CrossRef] 
70. Ligtenberg, M.J.; Kuiper, R.P.; Van Kessel, A.G.; Hoogerbrugge, N. EPCAM deletion carriers constitute a unique subgroup of Lynch syndrome patients. Fam. Cancer 2012, 12, 169-174. [CrossRef]

71. Watson, P.; Vasen, H.; Mecklin, J.-P.; Bernstein, I.T.; Aarnio, M.; Järvinen, H.J.; Myrhøj, T.; Sunde, L.; Wijnen, J.T.; Lynch, H.T. The risk of extra-colonic, extra-endometrial cancer in the Lynch syndrome. Int. J. Cancer 2008, 123, 444-449. [CrossRef] [PubMed]

72. Soravia, C.; Van Der Klift, H.; Bründler, M.-A.; Blouin, J.-L.; Wijnen, J.; Hutter, P.; Fodde, R.; DeLozier-Blanchet, C. Prostate cancer is part of the hereditary non-polyposis colorectal cancer (HNPCC) tumor spectrum. Am. J. Med. Genet. Part A 2003, 121, 159-162. [CrossRef] [PubMed]

73. Grindedal, E.M.; Moller, P.; Eeles, R.; Stormorken, A.T.; Bowitz-Lothe, I.M.; Landrø, S.M.; Clark, N.; Kvåle, R.; Shanley, S.; Maehle, L. Germ-Line Mutations in Mismatch Repair Genes Associated with Prostate Cancer. Cancer Epidemiol. Biomarkers Prev. 2009, 18, 2460-2467. [CrossRef] [PubMed]

74. Aarnio, M.; Sankila, R.; Pukkala, E.; Salovaara, R.; Aaltonen, L.A.; de la Chapelle, A.; Peltomäki, P.; Mecklin, J.; Järvinen, H.J. Cancer risk in mutation carriers of DNA-mismatch-repair genes. Int. J. Cancer 1999, 81, $214-218$. [CrossRef]

75. Pande, M.; Wei, C.; Chen, J.; Amos, C.I.; Lynch, P.M.; Lu, K.H.; Lucio, L.A.; Boyd-Rogers, S.G.; Bannon, S.A.; Mork, M.E.; et al. Cancer spectrum in DNA mismatch repair gene mutation carriers: Results from a hospital based Lynch syndrome registry. Fam. Cancer 2012, 11, 441-447. [CrossRef] [PubMed]

76. Engel, C.; Loeffler, M.; Steinke, V.; Rahner, N.; Holinski-Feder, E.; Dietmaier, W.; Schackert, H.K.; Goergens, H.; Doeberitz, M.V.K.; Goecke, T.; et al. Risks of Less Common Cancers in Proven Mutation Carriers With Lynch Syndrome. J. Clin. Oncol. 2012, 30, 4409-4415. [CrossRef]

77. Goecke, T.; Schulmann, K.; Engel, C.; Holinski-Feder, E.; Pagenstecher, C.; Schackert, H.K.; Kloor, M.; Kunstmann, E.; Vogelsang, H.; Keller, G.; et al. Genotype-Phenotype Comparison of German MLH1 and MSH2 Mutation Carriers Clinically Affected With Lynch Syndrome: A Report by the German HNPCC Consortium. J. Clin. Oncol. 2006, 24, 4285-4292. [CrossRef]

78. Lee, J.H.; Paull, T.T. Activation and regulation of ATM kinase activity in response to DNA double-strand breaks. Oncogene 2007, 26, 7741-7748. [CrossRef]

79. Bartek, J.; Lukas, J. Chk1 and Chk2 kinases in checkpoint control and cancer. Cancer Cell 2003, 3, 421-429. [CrossRef]

80. Choi, M.; Kipps, T.; Kurzrock, R. ATM Mutations in Cancer: Therapeutic Implications. Mol. Cancer Ther. 2016, 15, 1781-1791. [CrossRef]

81. Cybulski, C.; Wokołorczyk, D.; Jakubowska, A.; Huzarski, T.; Byrski, T.; Gronwald, J.; Masojć, B.; Dębniak, T.; Górski, B.; Blecharz, P.; et al. Risk of Breast Cancer in Women With a CHEK2 Mutation With and Without a Family History of Breast Cancer. J. Clin. Oncol. 2011, 29, 3747-3752. [CrossRef] [PubMed]

82. Southey, M.C.; Goldgar, D.E.; Winqvist, R.; Pylkäs, K.; Couch, F.; Tischkowitz, M.; Foulkes, W.D.; Dennis, J.; Michailidou, K.; Van Rensburg, E.J.; et al. PALB2, CHEK2 and ATM rare variants and cancer risk: Data from COGS. J. Med. Genet. 2016, 53, 800-811. [CrossRef] [PubMed]

83. Xiang, H.P.; Geng, X.P.; Ge, W.-W.; Li, H. Meta-analysis of CHEK2 1100delC variant and colorectal cancer susceptibility. Eur. J. Cancer 2011, 47, 2546-2551. [CrossRef] [PubMed]

84. Näslund-Koch, C.; Nordestgaard, B.G.; Bojesen, S.E. Increased Risk for Other Cancers in Addition to Breast Cancer for CHEK2*1100delC Heterozygotes Estimated From the Copenhagen General Population Study. J. Clin. Oncol. 2016, 34, 1208-1216. [CrossRef]

85. Seppälä, E.H.; Ikonen, T.; Mononen, N.; Autio, V.; Rökman, A.; Matikainen, M.P.; Tammela, T.L.J.; Schleutker, J. CHEK2 variants associate with hereditary prostate cancer. Br. J. Cancer 2003, 89, 1966-1970. [CrossRef] [PubMed]

86. Dong, X.; Wang, L.; Taniguchi, K.; Wang, X.; Cunningham, J.M.; McDonnell, S.; Qian, C.; Marks, A.F.; Slager, S.L.; Peterson, B.J.; et al. Mutations in CHEK2 Associated with Prostate Cancer Risk. Am. J. Hum. Genet. 2003, 72, 270-280. [CrossRef]

87. Leongamornlert, D.A.; Saunders, E.; Dadaev, T.; Tymrakiewicz, M.; Goh, C.; Jugurnauth-Little, S.; Kozarewa, I.; Fenwick, K.; Assiotis, I.; Barrowdale, D.; et al. Frequent germline deleterious mutations in DNA repair genes in familial prostate cancer cases are associated with advanced disease. Br. J. Cancer 2014, 110, 1663-1672. [CrossRef] 
88. Cybulski, C.; Wokołorczyk, D.; Kluźniak, W.; Jakubowska, A.; Górski, B.; Gronwald, J.; Huzarski, T.; Kashyap, A.; Byrski, T.; Dębniak, T.; et al. An inherited NBN mutation is associated with poor prognosis prostate cancer. Br. J. Cancer 2012, 108, 461-468. [CrossRef] [PubMed]

89. Paulo, P.; Maia, S.; Pinto, C.; Pinto, P.; Monteiro, A.; Peixoto, A.; Teixeira, M.R. Targeted next generation sequencing identifies functionally deleterious germline mutations in novel genes in early-onset/familial prostate cancer. PLoS Genet. 2018, 14, e1007355. [CrossRef] [PubMed]

90. Pritchard, C.C.; Mateo, J.; Walsh, M.F.; De Sarkar, N.; Abida, W.; Beltran, H.; Garofalo, A.; Gulati, R.; Carreira, S.; Eeles, R.; et al. Inherited DNA-Repair Gene Mutations in Men with Metastatic Prostate Cancer. N. Engl. J. Med. 2016, 375, 443-453. [CrossRef] [PubMed]

91. Rantapero, T.; Wahlfors, T.; Kähler, A.; Hultman, C.; Lindberg, J.; Tammela, T.L.J.; Nykter, M.; Schleutker, J.; Wiklund, F. Inherited DNA Repair Gene Mutations in Men with Lethal Prostate Cancer. Genes 2020, 11, 314. [CrossRef] [PubMed]

92. Zhang, F.; Ma, J.; Wu, J.; Ye, L.; Cai, H.; Xia, B.; Yu, X. PALB2 Links BRCA1 and BRCA2 in the DNA-Damage Response. Curr. Boil. 2009, 19, 524-529. [CrossRef] [PubMed]

93. Reid, S.; Schindler, D.; Hanenberg, H.; Barker, K.; Hanks, S.; Kalb, R.; Neveling, K.; Kelly, P.; Seal, S.; Freund, M.; et al. Biallelic mutations in PALB2 cause Fanconi anemia subtype FA-N and predispose to childhood cancer. Nat. Genet. 2006, 39, 162-164. [CrossRef]

94. Rahman, N.; Seal, S.; Thompson, D.; Kelly, P.; Renwick, A.; Elliott, A.; Reid, S.; Spanova, K.; Barfoot, R.; Chagtai, T.; et al. PALB2, which encodes a BRCA2-interacting protein, is a breast cancer susceptibility gene. Nat. Genet. 2006, 39, 165-167. [CrossRef]

95. Jones, S.; Hruban, R.H.; Kamiyama, M.; Borges, M.; Zhang, X.; Parsons, D.W.; Lin, J.C.-H.; Palmisano, E.; Brune, K.; Jaffee, E.M.; et al. Exomic Sequencing Identifies PALB2 as a Pancreatic Cancer Susceptibility Gene. Science 2009, 324, 217. [CrossRef] [PubMed]

96. Pilié, P.G.; Johnson, A.M.; Hanson, K.L.; Dayno, M.E.; Kapron, A.L.; Stoffel, E.M.; Cooney, K. Germline genetic variants in men with prostate cancer and one or more additional cancers. Cancer 2017, 123, 3925-3932. [CrossRef]

97. Erkko, H.; Xia, B.; Nikkilä, J.; Schleutker, J.; Syrjakoski, K.; Mannermaa, A.; Kallioniemi, A.; Pylkäs, K.; Karppinen, S.-M.; Rapakko, K.; et al. A recurrent mutation in PALB2 in Finnish cancer families. Nature 2007, 446, 316-319. [CrossRef]

98. Nicolosi, P.; Ledet, E.; Yang, S.; Michalski, S.; Freschi, B.; O’Leary, E.; Esplin, E.D.; Nussbaum, R.L.; Sartor, O. Prevalence of Germline Variants in Prostate Cancer and Implications for Current Genetic Testing Guidelines. JAMA Oncol. 2019, 5, 523-528. [CrossRef]

99. Horak, P.; Weischenfeldt, J.; Von Amsberg, G.; Beyer, B.; Schutte, A.; Uhrig, S.; Gieldon, L.; Klink, B.; Feuerbach, L.; Hübschmann, D.; et al. Response to olaparib in a PALB2 germline mutated prostate cancer and genetic events associated with resistance. Mol. Case Stud. 2019, 5. [CrossRef]

100. De Bono, J.S.; Mateo, J.; Fizazi, K.; Saad, F.; Shore, N.; Sandhu, S.; Chi, K.N.; Sartor, O.; Agarwal, N.; Olmos, D.; et al. Olaparib for Metastatic Castration-Resistant Prostate Cancer. N. Engl. J. Med. 2020, 382, 2091-2102. [CrossRef]

101. Cantor, S.B.; Bell, D.W.; Ganesan, S.; Kass, E.M.; Drapkin, R.; Grossman, S.; Wahrer, D.C.; Sgroi, D.C.; Lane, W.S.; Haber, D.A.; et al. BACH1, a Novel Helicase-like Protein, Interacts Directly with BRCA1 and Contributes to Its DNA Repair Function. Cell 2001, 105, 149-160. [CrossRef]

102. Seal, S.; Thompson, D.; Renwick, A.; Elliott, A.; Kelly, P.; Barfoot, R.; Chagtai, T.; Jayatilake, H.; Ahmed, M.; Spanova, K.; et al. Truncating mutations in the Fanconi anemia J gene BRIP1 are low-penetrance breast cancer susceptibility alleles. Nat. Genet. 2006, 38, 1239-1241. [CrossRef]

103. Ramus, S.J.; Song, H.; Dicks, E.; Tyrer, J.P.; Rosenthal, A.N.; Intermaggio, M.P.; Fraser, L.S.M.; Gentry-Maharaj, A.; Hayward, J.; Philpott, S.; et al. Germline Mutations in the BRIP1, BARD1, PALB2, and NBN Genes in Women With Ovarian Cancer. J. Natl. Cancer Inst. 2015, 107. [CrossRef] [PubMed]

104. Kote-Jarai, Z.; Jugurnauth, S.; Mulholland, S.; Leongamornlert, D.A.; Guy, M.; Edwards, S.; Tymrakiewitcz, M.; O'Brien, L.; Hall, A.; Wilkinson, R.; et al. A recurrent truncating germline mutation in the BRIP1/FANCJ gene and susceptibility to prostate cancer. Br. J. Cancer 2009, 100, 426-430. [CrossRef]

105. Varon, R.; Vissinga, C.; Platzer, M.; Cerosaletti, K.M.; Chrzanowska, K.; Saar, K.; Beckmann, G.; Seemanová, E.; Cooper, P.R.; Nowak, N.J.; et al. Nibrin, a novel DNA double-strand break repair protein, is mutated in Nijmegen breakage syndrome. Cell 1998, 93, 467-476. [CrossRef] 
106. Cybulski, C.; Górski, B.; Dębniak, T.; Gliniewicz, B.; Mierzejewski, M.; Masojć, B.; Jakubowska, A.; Matyjasik, J.; Złowocka, E.; Sikorski, A.; et al. NBS1 is a prostate cancer susceptibility gene. Cancer Res. 2004, 64, 1215-1219. [CrossRef] [PubMed]

107. Mijušković, M.; Saunders, E.; Leongamornlert, D.A.; Wakerell, S.; Whitmore, I.; Dadaev, T.; Cieza-Borrella, C.; Govindasami, K.; Brook, M.N.; Haiman, C.A.; et al. Rare germline variants in DNA repair genes and the angiogenesis pathway predispose prostate cancer patients to develop metastatic disease. Br. J. Cancer 2018, 119, 96-104. [CrossRef]

108. Angèle, S.; Falconer, A.; Edwards, S.M.; Dörk, T.; Bremer, M.; Moullan, N.; Chapot, B.; Muir, K.; Houlston, R.; Norman, A.R.; et al. ATM polymorphisms as risk factors for prostate cancer development. Br. J. Cancer 2004, 91, 783-787. [CrossRef] [PubMed]

109. Castro, E.; Romero-Laorden, N.; Del Pozo, A.; Lozano, R.; Medina, A.; Puente, J.; Piulats, J.M.; Lorente, D.; Saez, M.I.; Morales-Barrera, R.; et al. PROREPAIR-B: A Prospective Cohort Study of the Impact of Germline DNA Repair Mutations on the Outcomes of Patients With Metastatic Castration-Resistant Prostate Cancer. J. Clin. Oncol. 2019, 37, 490-503. [CrossRef]

110. Easton, D.F.; Steele, L.; Fields, P.; Ormiston, W.; Averill, D.; Daly, P.A.; McManus, R.; Neuhausen, S.L.; Ford, D.; Wooster, R.; et al. Cancer risks in two large breast cancer families linked to BRCA2 on chromosome 13q12-13. Am. J. Hum. Genet. 1997, 61, 120-128. [CrossRef]

111. Hale, V.; Weischer, M.; Park, J.Y. CHEK $2 * 1100$ delC Mutation and Risk of Prostate Cancer. Prostate Cancer 2014, 2014, 1-9. [CrossRef] [PubMed]

112. Wang, Y.; Dai, B.; Ye, D. CHEK2 mutation and risk of prostate cancer: A systematic review and meta-analysis. Int. J. Clin. Exp. Med. 2015, 8, 15708-15715. [PubMed]

113. Karlsson, R.; Aly, M.; Clements, M.; Zheng, L.; Adolfsson, J.; Xu, J.; Grönberg, H.; Wiklund, F. A Population-based Assessment of Germline HOXB13 G84E Mutation and Prostate Cancer Risk. Eur. Urol. 2014, 65, 169-176. [CrossRef] [PubMed]

114. Ryan, S.; Jenkins, M.A.; Win, A.K. Risk of Prostate Cancer in Lynch Syndrome: A Systematic Review and Meta-analysis. Cancer Epidemiol. Biomarkers Prev. 2014, 23, 437-449. [CrossRef] [PubMed]

115. Abida, W.; Cyrta, J.; Heller, G.; Prandi, D.; Armenia, J.; Coleman, I.; Cieslik, M.; Benelli, M.; Robinson, D.; Van Allen, E.M.; et al. Genomic correlates of clinical outcome in advanced prostate cancer. Proc. Natl. Acad. Sci. USA 2019, 116, 11428-11436. [CrossRef]

116. Stopsack, K.H.; Nandakumar, S.; Wibmer, A.G.; Haywood, S.; Weg, E.S.; Barnett, E.S.; Kim, C.J.; Carbone, E.A.; Vasselman, S.E.; Nguyen, B.; et al. Oncogenic genomic alterations, clinical phenotypes, and outcomes in metastatic castration-sensitive prostate cancer. Clin. Cancer Res. 2020. [CrossRef]

117. Antonarakis, E.S.; Lu, C.; Luber, B.; Liang, C.; Wang, H.; Chen, Y.; Silberstein, J.L.; Piana, D.; Lai, Z.; Chen, Y.; et al. Germline DNA-repair Gene Mutations and Outcomes in Men with Metastatic Castration-resistant Prostate Cancer Receiving First-line Abiraterone and Enzalutamide. Eur. Urol. 2018, 74, 218-225. [CrossRef]

118. Nguyen-Dumont, T.; MacInnis, R.J.; Steen, J.A.; Theys, D.; Tsimiklis, H.; Hammet, F.; Mahmoodi, M.; Pope, B.J.; Park, D.J.; Mahmood, K.; et al. Rare germline genetic variants and risk of aggressive prostate cancer. Int. J. Cancer 2020. [CrossRef]

119. Abeshouse, A.; Ahn, J.; Akbani, R.; Ally, A.; Amin, S.; Andry, C.D.; Annala, M.; Aprikian, A.; Armenia, J.; Arora, A.; et al. The Molecular Taxonomy of Primary Prostate Cancer. Cell 2015, 163, 1011-1025. [CrossRef]

120. Rosty, C.; Walsh, M.D.; Lindor, N.M.; Thibodeau, S.N.; Mundt, E.; Gallinger, S.; Aronson, M.; Pollett, A.; Baron, J.A.; Pearson, S.; et al. High prevalence of mismatch repair deficiency in prostate cancers diagnosed in mismatch repair gene mutation carriers from the colon cancer family registry. Fam. Cancer 2014, 13, 573-582. [CrossRef]

121. Tam, V.; Patel, N.; Turcotte, M.; Bossé, Y.; Paré, G.; Meyre, D. Benefits and limitations of genome-wide association studies. Nat. Rev. Genet. 2019, 20, 467-484. [CrossRef] [PubMed]

122. Korte, A.; Farlow, A. The advantages and limitations of trait analysis with GWAS: A review. Plant Methods 2013, 9, 29. [CrossRef] [PubMed]

123. Milne, R.L.; ABCTB Investigators; Kuchenbaecker, K.B.; Michailidou, K.; Beesley, J.; Kar, S.P.; Lindström, S.; Hui, S.; Lemaçon, A.; Soucy, P.; et al. Identification of ten variants associated with risk of estrogen-receptornegative breast cancer. Nat. Genet. 2017, 49, 1767-1778. [CrossRef] [PubMed] 
124. Law, P.J.; The PRACTICAL Consortium; Timofeeva, M.; Fernandez-Rozadilla, C.; Broderick, P.; Studd, J.B.; Fernandez-Tajes, J.; Farrington, S.M.; Svinti, V.; Palles, C.; et al. Association analyses identify 31 new risk loci for colorectal cancer susceptibility. Nat. Commun. 2019, 10, 2154. [CrossRef] [PubMed]

125. Benafif, S.; Kote-Jarai, Z.; Eeles, R.A.; PRACTICAL Consortium. A Review of Prostate Cancer Genome-Wide Association Studies (GWAS). Cancer Epidemiol. Biomarkers Prev. 2018, 27, 845-857. [CrossRef] [PubMed]

126. Cheng, I.; Chen, G.K.; Nakagawa, H.; He, J.; Wan, P.; Laurie, C.C.; Shen, J.; Sheng, X.; Pooler, L.C.; Crenshaw, A.T.; et al. Evaluating genetic risk for prostate cancer among Japanese and Latinos. Cancer Epidemiol. Biomarkers Prev. 2012, 21, 2048-2058. [CrossRef]

127. Haiman, C.A.; Chen, G.K.; Blot, W.J.; Strom, S.S.; Berndt, S.I.; Kittles, R.A.; Rybicki, B.A.; Isaacs, W.B.; Ingles, S.A.; Stanford, J.L.; et al. Genome-wide association study of prostate cancer in men of African ancestry identifies a susceptibility locus at 17q21. Nat. Genet. 2011, 43, 570-573. [CrossRef]

128. Takata, R.; Akamatsu, S.; Kubo, M.; Takahashi, A.; Hosono, N.; Kawaguchi, T.; Tsunoda, T.; Inazawa, J.; Kamatani, N.; Ogawa, O.; et al. Genome-wide association study identifies five new susceptibility loci for prostate cancer in the Japanese population. Nat. Genet. 2010, 42, 751-754. [CrossRef]

129. Han, Y.; Signorello, L.B.; Strom, S.S.; Kittles, R.A.; Rybicki, B.A.; Stanford, J.L.; Goodman, P.J.; Berndt, S.I.; Carpten, J.; Casey, G.; et al. Generalizability of established prostate cancer risk variants in men of African ancestry. Int. J. Cancer 2014, 136, 1210-1217. [CrossRef]

130. Matejcic, M.; The PRACTICAL (Prostate Cancer Association Group to Investigate Cancer-Associated Alterations in the Genome) Consortium; Saunders, E.; Dadaev, T.; Brook, M.N.; Wang, K.; Sheng, X.; Al Olama, A.A.; Schumacher, F.R.; Ingles, S.A.; et al. Germline variation at 8q24 and prostate cancer risk in men of European ancestry. Nat. Commun. 2018, 9, 4616. [CrossRef]

131. Liu, M.; Wang, J.; Xu, Y.; Wei, D.; Shi, X.; Yang, Z. Risk Loci on Chromosome 8q24 are Associated With Prostate Cancer in Northern Chinese Men. J. Urol. 2012, 187, 315-321. [CrossRef] [PubMed]

132. Hindorff, L.A.; Sethupathy, P.; Junkins, H.A.; Ramos, E.M.; Mehta, J.P.; Collins, F.S.; Manolio, T.A. Potential etiologic and functional implications of genome-wide association loci for human diseases and traits. Proc. Natl. Acad. Sci. USA 2009, 106, 9362-9367. [CrossRef] [PubMed]

133. Jin, H.-J.; Jung, S.; Debroy, A.R.; Davuluri, R. Identification and validation of regulatory SNPs that modulate transcription factor chromatin binding and gene expression in prostate cancer. Oncotarget 2016, 7, 54616-54626. [CrossRef]

134. Farashi, S.; Kryza, T.; Batra, J. Pathway Analysis of Genes Identified through Post-GWAS to Underpin Prostate Cancer Aetiology. Genes 2020, 11, 526. [CrossRef]

135. Huang, Q.; Whitington, T.; Gao, P.; Lindberg, J.; Yang, Y.; Sun, J.; Väisänen, M.-R.; Szulkin, R.; Annala, M.; Yan, J.; et al. A prostate cancer susceptibility allele at 6q22 increases RFX6 expression by modulating HOXB13 chromatin binding. Nat. Genet. 2014, 46, 126-135. [CrossRef] [PubMed]

136. Kote-Jarai, Z.; Saunders, E.; Leongamornlert, D.A.; Tymrakiewicz, M.; Dadaev, T.; Jugurnauth-Little, S.; Ross-Adams, H.; Al Olama, A.A.; Benlloch, S.; Halim, S.; et al. Fine-mapping identifies multiple prostate cancer risk loci at 5p15, one of which associates with TERT expression. Hum. Mol. Genet. 2013, 22, 2520-2528. [CrossRef]

137. Farashi, S.; Kryza, T.; Clements, J.; Batra, J. Post-GWAS in prostate cancer: From genetic association to biological contribution. Nat. Rev. Cancer 2018, 19, 46-59. [CrossRef] [PubMed]

138. Bu, H.; Narisu, N.; Schlick, B.; Rainer, J.; Manke, T.; Schäfer, G.; Pasqualini, L.; Chines, P.; Schweiger, M.R.; Fuchsberger, C.; et al. Putative Prostate Cancer Risk SNP in an Androgen Receptor-Binding Site of the Melanophilin Gene Illustrates Enrichment of Risk SNPs in Androgen Receptor Target Sites. Hum. Mutat. 2015, 37, 52-64. [CrossRef]

139. Whitington, T.; Gao, P.; Song, W.; Ross-Adams, H.; Lamb, A.D.; Yang, Y.; Svezia, I.; Klevebring, D.; Mills, I.G.; Karlsson, R.; et al. Gene regulatory mechanisms underpinning prostate cancer susceptibility. Nat. Genet. 2016, 48, 387-397. [CrossRef]

140. MacInnis, R.J.; Antoniou, A.C.; Eeles, R.; Severi, G.; Al Olama, A.A.; McGuffog, L.; Kote-Jarai, Z.; Guy, M.; O'Brien, L.T.; Hall, A.L.; et al. A risk prediction algorithm based on family history and common genetic variants: Application to prostate cancer with potential clinical impact. Genet. Epidemiology 2011, 35, 549-556. [CrossRef] 
141. Szulkin, R.; Karlsson, R.; Whitington, T.; Aly, M.; Gronberg, H.; Eeles, R.; Easton, U.F.; Kote-Jarai, Z.; Al Olama, A.A.; Benlloch, S.; et al. Genome-wide association study of prostate cancer-specific survival. Cancer Epidemiol. Biomarkers Prev. 2015, 24, 1796-1800. [CrossRef]

142. Mohler, J.L. The 2010 NCCN Clinical Practice Guidelines in Oncology on Prostate Cancer. J. Natl. Compr. Cancer Netw. 2010, 8, 145. [CrossRef]

143. Oliveri, S.; Ferrari, F.; Manfrinati, A.; Pravettoni, G. A Systematic Review of the Psychological Implications of Genetic Testing: A Comparative Analysis Among Cardiovascular, Neurodegenerative and Cancer Diseases. Front. Genet. 2018, 9, 9. [CrossRef]

144. Snyder, C. Evolution of cancer risk assessment and counseling related to psychological, financial and legal implications. Fam. Cancer 2016, 15, 493-496. [CrossRef] [PubMed]

145. Chowdhury, S.; Dent, T.; Pashayan, N.; Hall, A.; Lyratzopoulos, G.; Hallowell, N.; Hall, P.; Pharoah, P.; Burton, $\mathrm{H}$. Incorporating genomics into breast and prostate cancer screening: Assessing the implications. Genet. Med. 2013, 15, 423-432. [CrossRef]

146. Dinerman, B.F.; Bernstein, A.N.; Khani, F.; Hu, J.C. Intraductal Carcinoma of the Prostate: A Risk for Rapid Recurrence. Urology 2017, 105, e1-e2. [CrossRef] [PubMed]

147. Velho, P.I.; Silberstein, J.L.; Markowski, M.C.; Luo, J.; Lotan, T.L.; Isaacs, W.B.; Antonarakis, E.S. Intraductal/ ductal histology and lymphovascular invasion are associated with germline DNA-repair gene mutations in prostate cancer. Prostate 2018, 78, 401-407. [CrossRef] [PubMed]

148. Risbridger, G.P.; Taylor, R.A.; Clouston, D.; Sliwinski, A.; Thorne, H.; Hunter, S.; Li, J.; Mitchell, G.; Murphy, D.; Frydenberg, M.; et al. Patient-derived Xenografts Reveal that Intraductal Carcinoma of the Prostate Is a Prominent Pathology in BRCA2 Mutation Carriers with Prostate Cancer and Correlates with Poor Prognosis. Eur. Urol. 2015, 67, 496-503. [CrossRef] [PubMed]

149. Salinas, C.A.; Tsodikov, A.; Ishak-Howard, M.; Cooney, K. Prostate cancer in young men: An important clinical entity. Nat. Rev. Urol. 2014, 11,317-323. [CrossRef] [PubMed]

150. Lange, E.M.; Salinas, C.A.; Zuhlke, K.A.; Ray, A.M.; Wang, Y.; Lu, Y.; Ho, L.A.; Luo, J.; Cooney, K. Early onset prostate cancer has a significant genetic component. Prostate 2011, 72, 147-156. [CrossRef] [PubMed]

151. Harris, R. Practical Genetic Counselling. J. Med. Genet. 1989, 26, 799. [CrossRef]

152. Yang, M.; Kim, J.W. Principles of Genetic Counseling in the Era of Next-Generation Sequencing. Ann. Lab. Med. 2018, 38, 291-295. [CrossRef] [PubMed]

153. Giri, V.N.; Hegarty, S.; Hyatt, C.; O’Leary, E.; Garcia, J.; Knudsen, K.E.; Kelly, W.K.; Gomella, L.G. Germline genetic testing for inherited prostate cancer in practice: Implications for genetic testing, precision therapy, and cascade testing. Prostate 2018, 79, 333-339. [CrossRef] [PubMed]

154. National Comprehensive Cancer Network. NCCN Clinical Practice Guidelines in Oncology-Prostate Cancer Early Detection, Version 2. 2019. Available online: www.nccn.org/professionals/physician_gls/pdf/ prostate_detection.pdf (accessed on 5 June 2020).

155. European Association of Urology. Prostate Cancer. Available online: https://uroweb.org/guideline/prostatecancer/ (accessed on 5 June 2020).

156. American Cancer Society. American Cancer Society Recommendations for Prostate Cancer Early Detection. Available online: https://www.cancer.org/cancer/prostate-cancer/detection-diagnosis-staging/acsrecommendations.html (accessed on 5 June 2020).

157. Robinson, D.; Van Allen, E.M.; Wu, Y.M.; Schultz, N.; Lonigro, R.J.; Mosquera, J.M.; Montgomery, B.; Taplin, M.E.; Pritchard, C.C.; Attard, G.; et al. Integrative Clinical Genomics of Advanced Prostate Cancer. Cell 2015, 161, 1215-1228. [CrossRef]

158. Na, R.; Zheng, S.L.; Han, M.; Yu, H.; Jiang, D.; Shah, S.; Ewing, C.M.; Zhang, L.; Novakovic, K.; Petkewicz, J.; et al. Germline Mutations in ATM and BRCA1/2 Distinguish Risk for Lethal and Indolent Prostate Cancer and are Associated with Early Age at Death. Eur. Urol. 2016, 71, 740-747. [CrossRef]

159. Castro, E.; Goh, C.; Olmos, D.; Saunders, E.; Leongamornlert, D.A.; Tymrakiewicz, M.; Mahmud, N.; Dadaev, T.; Govindasami, K.; Guy, M.; et al. Germline BRCA Mutations Are Associated With Higher Risk of Nodal Involvement, Distant Metastasis, and Poor Survival Outcomes in Prostate Cancer. J. Clin. Oncol. 2013, 31, 1748-1757. [CrossRef]

160. Akbari, M.R.; Wallis, C.J.D.; Toi, A.; Trachtenberg, J.; Sun, P.; Narod, S.A.; Nam, R.K. The impact of a BRCA2 mutation on mortality from screen-detected prostate cancer. Br. J. Cancer 2014, 111, 1238-1240. [CrossRef] [PubMed] 
161. Marshall, C.H.; Sokolova, A.O.; McNatty, A.L.; Cheng, H.H.; Eisenberger, M.A.; Bryce, A.H.; Schweizer, M.T.; Antonarakis, E.S. Differential Response to Olaparib Treatment Among Men with Metastatic Castration-resistant Prostate Cancer Harboring BRCA1 or BRCA2 Versus ATM Mutations. Eur. Urol. 2019, 76, 452-458. [CrossRef] [PubMed]

162. Clarke, N.; Wiechno, P.; Alekseev, B.; Sala, N.; Jones, R.; Kocak, I.; Chiuri, V.E.; Jassem, J.; Fléchon, A.; Redfern, C.; et al. Olaparib combined with abiraterone in patients with metastatic castration-resistant prostate cancer: A randomised, double-blind, placebo-controlled, phase 2 trial. Lancet Oncol. 2018, 19, 975-986. [CrossRef]

163. D'Andrea, A. Mechanisms of PARP inhibitor sensitivity and resistance. DNA Repair 2018, 71, $172-176$. [CrossRef] [PubMed]

164. Maya-Mendoza, A.; Moudry, P.; Merchut-Maya, J.M.; Lee, M.; Strauss, R.; Bartek, J. High speed of fork progression induces DNA replication stress and genomic instability. Nature 2018, 559, 279-284. [CrossRef] [PubMed]

165. Godon, C.; Cordelières, F.P.; Biard, D.S.F.; Giocanti, N.; Mégnin-Chanet, F.; Hall, J.; Favaudon, V. PARP inhibition versus PARP-1 silencing: Different outcomes in terms of single-strand break repair and radiation susceptibility. Nucleic Acids Res. 2008, 36, 4454-4464. [CrossRef] [PubMed]

166. Livraghi, L.; Garber, J.E. PARP inhibitors in the management of breast cancer: Current data and future prospects. BMC Med. 2015, 13, 188. [CrossRef] [PubMed]

167. Kaufman, B.; Shapira-Frommer, R.; Schmutzler, R.K.; Audeh, M.W.; Friedlander, M.; Balmaña, J.; Mitchell, G.; Fried, G.; Stemmer, S.M.; Hubert, A.; et al. Olaparib Monotherapy in Patients With Advanced Cancer and a Germline BRCA1/2 Mutation. J. Clin. Oncol. 2015, 33, 244-250. [CrossRef]

168. Karzai, F.; VanderWeele, D.J.; Madan, R.A.; Owens, H.; Cordes, L.M.; Hankin, A.; Couvillon, A.; Nichols, E.; Bilusic, M.; Beshiri, M.L.; et al. Activity of durvalumab plus olaparib in metastatic castration-resistant prostate cancer in men with and without DNA damage repair mutations. J. Immunother. Cancer 2018, 6, 141. [CrossRef] [PubMed]

169. Kamel, D.; Gray, C.; Walia, J.S.; Kumar, V.; Walia, J. PARP Inhibitor Drugs in the Treatment of Breast, Ovarian, Prostate and Pancreatic Cancers: An Update of Clinical Trials. Curr. Drug Targets 2018, 19, 21-37. [CrossRef]

170. Abida, W.; Bryce, A.; Vogelzang, N.; Amato, R.; Percent, I.; Shapiro, J.; McDermott, R.; Hussain, A.; Patnaik, A.; Petrylak, D.; et al. Preliminary results from TRITON2: A phase II study of rucaparib in patients (pts) with metastatic castration-resistant prostate cancer (mCRPC) associated with homologous recombination repair (HRR) gene alterations. Ann. Oncol. 2018, 29, viii272. [CrossRef]

171. Pomerantz, M.M.; Spisák, S.; Jia, L.; Cronin, A.M.; Csabai, I.; Ledet, E.; Sartor, A.O.; Rainville, I.; O'Connor, E.P.; Herbert, Z.T.; et al. The association between germline BRCA2 variants and sensitivity to platinum-based chemotherapy among men with metastatic prostate cancer. Cancer 2017, 123, 3532-3539. [CrossRef]

172. Zafeiriou, Z.; Bianchini, D.; Chandler, R.; Rescigno, P.; Yuan, W.; Carreira, S.; Barrero, M.; Petremolo, A.; Miranda, S.; Riisnaes, R.; et al. Genomic Analysis of Three Metastatic Prostate Cancer Patients with Exceptional Responses to Carboplatin Indicating Different Types of DNA Repair Deficiency. Eur. Urol. 2018, 75, 184-192. [CrossRef]

173. Antonarakis, E.S.; Shaukat, F.; Velho, P.I.; Kaur, H.; Shenderov, E.; Pardoll, E.M.; Lotan, T.L. Clinical Features and Therapeutic Outcomes in Men with Advanced Prostate Cancer and DNA Mismatch Repair Gene Mutations. Eur. Urol. 2019, 75, 378-382. [CrossRef]

174. Le, D.T.; Durham, J.N.; Smith, K.N.; Wang, H.; Bartlett, B.R.; Aulakh, L.K.; Lu, S.; Kemberling, H.; Wilt, C.; Luber, B.S.; et al. Mismatch repair deficiency predicts response of solid tumors to PD-1 blockade. Science 2017, 357, 409-413. [CrossRef] [PubMed]

175. Graff, J.N.; Alumkal, J.J.; Drake, C.G.; Thomas, G.V.; Redmond, W.L.; Farhad, M.; Cetnar, J.P.; Ey, F.S.; Bergan, R.C.; Slottke, R.; et al. Early evidence of anti-PD-1 activity in enzalutamide-resistant prostate cancer. Oncotarget 2016, 7, 52810-52817. [CrossRef]

176. Velho, P.I.; Antonarakis, E.S. PD-1/PD-L1 pathway inhibitors in advanced prostate cancer. Expert Rev. Clin. Pharmacol. 2018, 11, 475-486. [CrossRef] [PubMed]

177. Mohler, J.L.; Antonarakis, E.S.; Armstrong, A.J.; D’Amico, A.V.; Davis, B.J.; Dorff, T.; Eastham, J.A.; Enke, C.A.; Farrington, T.A.; Higano, C.S.; et al. Prostate Cancer, Version 2.2019, NCCN Clinical Practice Guidelines in Oncology. J. Natl. Compr. Cancer Netw. 2019, 17, 479-505. [CrossRef] [PubMed] 
178. Mersch, J.; Brown, N.; Pirzadeh-Miller, S.; Mundt, E.; Cox, H.C.; Brown, K.; Aston, M.; Esterling, L.; Manley, S.; Ross, T.S. Prevalence of Variant Reclassification Following Hereditary Cancer Genetic Testing. JAMA 2018, 320, 1266-1274. [CrossRef] [PubMed]

179. 7Turner, S.A.; Rao, S.K.; Morgan, R.H.; Vnencak-Jones, C.L.; Wiesner, G.L. The impact of variant clasification on the clinical management of hereditary cancer syndromes. Genet. Med. 2018, 21, 426-430. [CrossRef] [PubMed]

180. Hegde, M.; Bale, S.; Bayrak-Toydemir, P.; Gibson, J.; Jeng, L.J.B.; Joseph, L.; Laser, J.; Lubin, I.M.; Miller, C.E.; Ross, L.F.; et al. Reporting incidental findings in genomic scale clinical sequencing-a clinical laboratory perspective: A report of the Association for Molecular Pathology. J. Mol. Diagn. 2015, 17, 107-117. [CrossRef]

181. Kalia, S.S.; ACMG Secondary Findings Maintenance Working Group; Adelman, K.; Bale, S.J.; Chung, W.K.; Eng, C.; Evans, J.P.; Herman, G.E.; Hufnagel, S.B.; Klein, T.E.; et al. Recommendations for reporting of secondary findings in clinical exome and genome sequencing, 2016 update (ACMG SF v2.0): A policy statement of the American College of Medical Genetics and Genomics. Genet. Med. 2016, 19, $249-255$. [CrossRef]

(C) 2020 by the authors. Licensee MDPI, Basel, Switzerland. This article is an open access article distributed under the terms and conditions of the Creative Commons Attribution (CC BY) license (http://creativecommons.org/licenses/by/4.0/). 